\title{
Features and Methods of Human Age Estimation: Opportunities and Challenges in Medical Image Processing
}

\author{
Kirti A. Patil ${ }^{1}$, R. P. Bhavsar ${ }^{2}$, B. V. Pawar ${ }^{3}$ \\ ${ }^{1}$ MET's Institute of Engineering, BKC, Nashik, India \\ ${ }^{2}$ School of Computer Sciences, NMU, Jalgaon, India \\ ${ }^{3}$ School of Computer Sciences, NMU, Jalgaon, India \\ kirti.patil2004@gmail.com ${ }^{1}$, rpbhavsar@nmu.ac.in ${ }^{2}$, bvpawar@nmu.ac.in ${ }^{3}$
}

Article History: Received: 10 November 2020; Revised: 12 January 2021; Accepted: 27 January 2021; Published online: 05 April 2021

\begin{abstract}
Age estimation of living species is an open and interesting problem due to its medico-legal importance and humans are no exception to this. Human body undergoes various physiological changes such as facial wrinkles, walking habits. Besides this, biological changes also help in human age estimation. Some of the changes are body skeleton and craniofacial growth. Various age estimation methods viz. manual, semi-automated and automated methods are available. Each of these methods has their merits and demerits. The popular manual and semi-automated age estimation methods are prone to human observation error and need sophisticated equipments. The advent of computational methods has opened new possibilities towards automation of the problem. Hence there is growing interest in fully automated methods. Through this paper, we have discussed different aspects of human age estimation and presented a brief review of various available methods.
\end{abstract}

Keywords: Skeletal growth, age estimation, gender estimation, aging features, medical image analysis, forensic science, human identification, neural network.

\section{Introduction}

Every day, in medico-legal practice, forensic sciences laboratories, and criminal cases, human age estimation arises some questions. Whether the human was a foetus or a new born baby or it may be a young child to an old age person? In some cases, where bodies are found decomposed or scattered remains collected from bomb blast, buried bodies, human remains, human identification required at every development stage right from infancy to old age period or at death. Surprisingly, there are number of situations where people are either unable to tell the authorities when they were born or wish to hide the personal details, most importantly 'age' in this digital world. Generally, the chronological age of a human is known as a measure of the period of time that has passed since they were born $[1,2]$. However, if the date of birth is unknown, is concealed or is falsely attested then biological age is usually selected as the most relevant factor for further investigation. Biological age is generally recognised through identification of growth and maturational milestones achieved either in the skeleton (skeletal age), the dentition (dental age) or soft tissue developments in human body [1]. Age, gender, race, ethnicity are new dimensions to human identification and can be predicted with different body part features. Age is considered as a significant factor in criminal laws, immigration law or social services to take just some examples. Legislation regulating process judicial rules of age limit varies from country to country. Table 1 lists features used in human development stages, body part features and medico-legal importance of age according to Indian law.

Fingerprints, iris examinations in children are exceptionally difficult to match as it would be falsely rejected by the systems. Many papers based on fingerprint, iris, whole blood, face, voice etc. are used to identify a specific age group. As table 1 shows dental development and skeletal development are the major continuous processes in human development. Papers that are based on dental and skeletal developments are manual and semi-automated approaches for human identification. Very few papers have proposed fully automated approaches.

Table 1. Human body part features in development stages and its medico-legal importance as in Indian law [1,2]

\begin{tabular}{|c|c|c|}
\hline Age range & Body part feature & $\begin{array}{l}\text { Medico-legal Importance as in Indian } \\
\text { law }\end{array}$ \\
\hline $\begin{array}{l}\text { Foetus } \\
\text { (Intra-uterine } \\
\text { life: } \quad 0-9 \\
\text { months) }\end{array}$ & $\begin{array}{l}\text { - Observation of umbilical cord } \\
\text { - Pre-cursor of ossification nuclei } \\
\text { - Brain development }\end{array}$ & - Prohibition of gender prediction \\
\hline $\begin{array}{l}\text { Infancy } \\
(0-2 \text { years })\end{array}$ & $\begin{array}{l}\text { - Primary Dentition/eruption } \\
\text { - Primary centers of ossification in handwrist } \\
\text { bone metacarpals }\end{array}$ & - Ordinarily in custody of mother \\
\hline
\end{tabular}




\begin{tabular}{|c|c|c|}
\hline & - Brain development & \\
\hline $\begin{array}{l}\text { Childhood } \\
(3-7 \text { years })\end{array}$ & $\begin{array}{l}\text { - } \text { Emergence of last deciduous molar } \\
\text { - } \text { Bone dimensions } \\
\text { - Hand wrist bone carpals and metacarpals } \\
\text { - Harris line clear indication } \\
\text { - } \text { Craniofacial growth } \\
\end{array}$ & $\begin{array}{l}\text { - Prohibition of employment in factories } \\
\text { - Ordinarily in custody of mother } \\
\text { - Not capable of committing an offense } \\
\text { under } 12 \text { years }\end{array}$ \\
\hline $\begin{array}{l}\text { Juvenile } \\
\text { (8-10 years) }\end{array}$ & $\begin{array}{ll}\text { - } & \text { Eruption of first permanent molar } \\
\text { - } & \text { Epiphyseal fusion } \\
\text { - } & \text { Hand wrist bone carpals and metacarpals } \\
\text { - } & \text { Craniofacial growth } \\
\end{array}$ & $\begin{array}{l}\text { - Prohibition of employment in factories } \\
\text { - Not capable of committing an offense } \\
\text { under } 12 \text { years }\end{array}$ \\
\hline $\begin{array}{l}\text { Adolescence } \\
(11-18 \text { years })\end{array}$ & 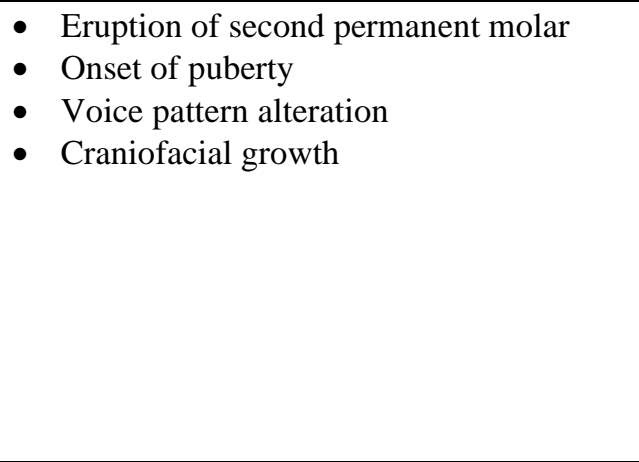 & $\begin{array}{l}\text { - Prohibition of employment in factories } \\
\text { under } 14 \text { years } \\
\text { - Not capable of committing an offense } \\
\text { under } 12 \text { years } \\
\text { - Cannot be kept in jail below } 16 \text { years } \\
\text { - Age of marriage in female at } 18 \text { years } \\
\text { - Age of marriage in male at } 21 \text { years } \\
\text { - Guardianship orders } \\
\text { - Age of employment } \\
\text { - Prohibition of purchasing tobacco, } \\
\text { pornography, lottery tickets }\end{array}$ \\
\hline $\begin{array}{l}\text { Young adult } \\
\text { (18-40 years) }\end{array}$ & $\begin{array}{ll}\text { - } & \text { Third Molar Development } \\
\text { - } & \text { Diaphyseal fusion } \\
\text { - } & \text { Hand wrist bone development } \\
\text { - } & \text { Clavicle sternal end fusion } \\
\text { - } & \text { Closing of cranial sutures } \\
\end{array}$ & $\begin{array}{l}\text { - } \text { Voting rights } \\
\text { - Employment age } \\
\text { - Driving license } \\
\text { - Obtain housing and motor vehicles }\end{array}$ \\
\hline $\begin{array}{l}\text { Adults } \\
\text { (30-60 years) }\end{array}$ & $\begin{array}{l}\text { - } \text { Pubic Synthesis } \\
\text { - Auricular surface changes } \\
\text { - } \text { Acetabular surface changes } \\
\text { - Sternal end of ribs } \\
\text { - Closing of Sagittal sutures } \\
\text { - Facial elasticity, wrinkles, texture, colour } \\
\text { - Voice pattern alteration }\end{array}$ & $\begin{array}{ll}\text { - } & \text { Voting rights } \\
\text { - } & \text { Employment age } \\
\text { - } & \text { Driving license } \\
\text { - } & \text { Obtain housing and motor vehicles }\end{array}$ \\
\hline $\begin{array}{l}\text { Old age } \\
(60+\text { years })\end{array}$ & $\begin{array}{l}\text { - Union of whole body } \\
\text { - Manubrium of sternum appears }\end{array}$ & $\begin{array}{l}\text { - } \text { Retirement benefits } \\
\text { - } \text { Pension Claims }\end{array}$ \\
\hline
\end{tabular}

\section{Background}

\subsection{Types of Human Aging Features}

Automatic human identification systems that recognizes human age from various aging features is very challenging task. Aging features are the necessary information carrier that reflects lots of properties of human body parts from birth to old age. Aging features are divided into physiological and biological aging features. Physiological and biological aging features are used in numerous applications of medicine and forensic science. It was found that face was often used as prominent body part, other than this; short and long bones such as femur, clavicle, hand-wrist, skull bones and dental examination could also be used for human trait identification for higher precision. Physiological aging features include teeth, speech or voice patterns, gait, race, signature dynamics and hand geometry. These aging features includes feature descriptors such as change in shape in overall appearance resulting from sagging, change in colour resulting from aging and change in texture of pattern resulting from voice, gait, way of writing, wrinkling, and skin elasticity and biological aging features include bone, cartilage, fingerprints, iris, palmprint, Deoxyribonucleic Acid (DNA) and odour/scent. The biological aging features include feature descriptors such as height, width, diameter measurements of short and long bones, curvatures, directions patterns in fingerprints or palmprints etc. The study considers some of the above mentioned and more common circumstances that result in individuals. 


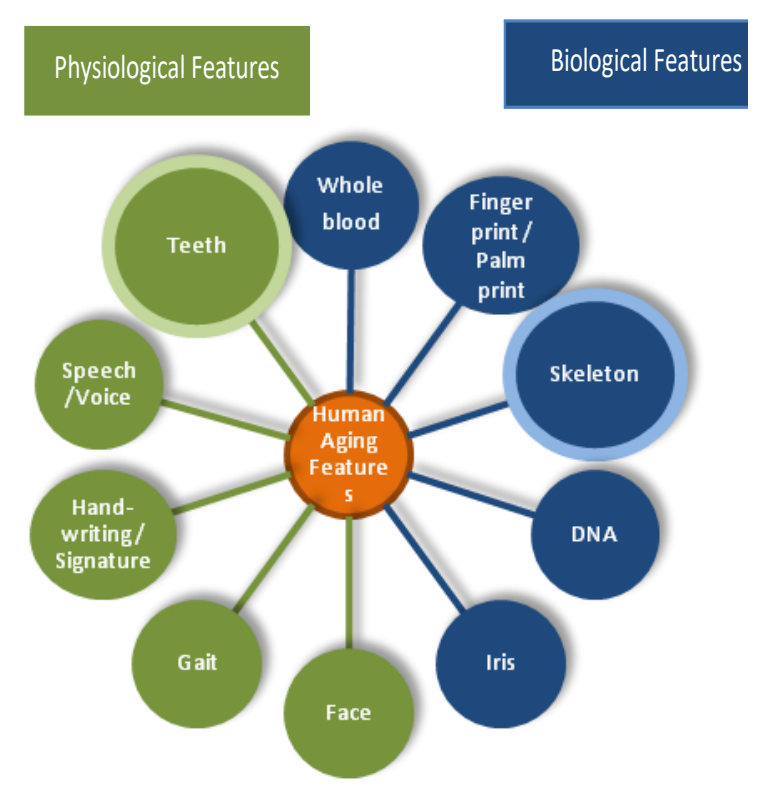

Figure 1. Types of Human Aging Features

According to investigation, age estimation techniques are classified into histological method, Clinical or visual observation, Atlas method and Automated method.

Histological method (Manual Process): Histological methods require the preparation of the tissues for detailed microscopic examination of blood cells, cross-sections of bone, teeth, skull which can determine more accurately the stage of development. This technique is more appropriate for post-mortem situations and mostly observed in finding age at death.

Clinical or visual observation (Manual Process): Clinical or visual observation of the growth stages of eruption of the teeth, skeletal development and changes in vocal cord, human trait, handwriting can give an approximate estimate of age. Table 2 lists Skeletal and Dental growth stages.

Atlas method (Semi-automated methods): This method has been widely used for anatomical structure localization. An image with ground truth labels of the anatomical structures of interest is taken as reference image or also called as Atlas. Localization is performed by a new unseen image to reference image using registration technique. Labels from are propagated to the input image thus obtaining in the location of anatomical structures. In multiclass approach an input image is registered to multiple reference images.

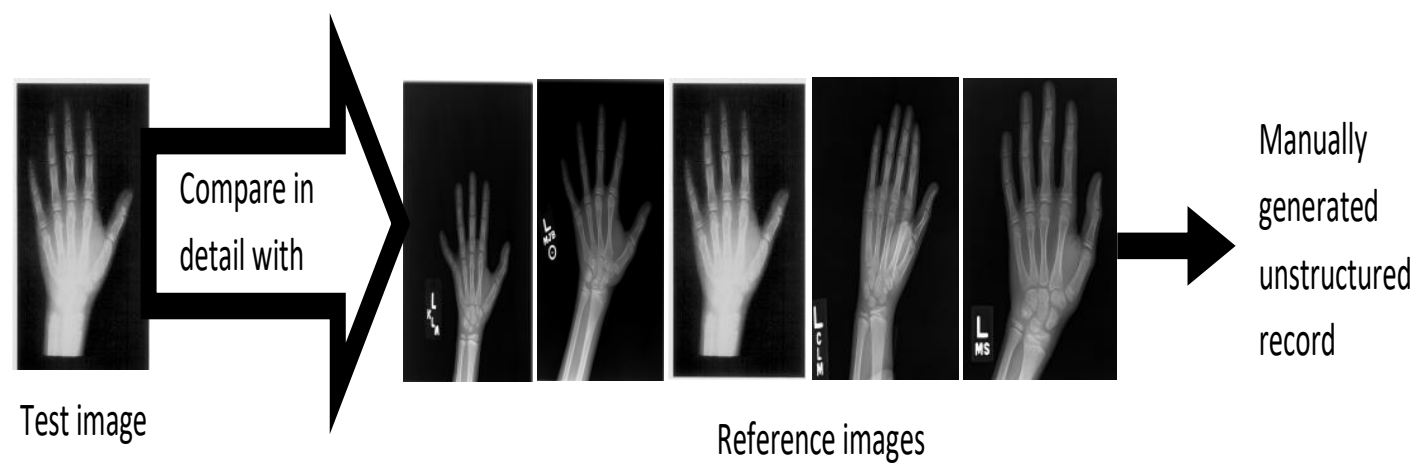

Figure 2. Atlas Method 
Table 2. Skeletal and tooth growth stages $[1,2]$ Skeletal Growth Stages

\begin{tabular}{|c|c|}
\hline Stage 1: Ossification centre not ossified. & $\begin{array}{l}\text { Stage A: cusp tips are mineralized but have not yet } \\
\text { coalesced. }\end{array}$ \\
\hline $\begin{array}{l}\text { Stage 2: Ossification centre ossified, epiphyseal } \\
\text { plate not ossified. }\end{array}$ & $\begin{array}{l}\text { Stage B: mineralized cusps are united so the mature } \\
\text { coronal morphology was well defined. }\end{array}$ \\
\hline Stage 3: Epiphyseal plate partly ossified. & $\begin{array}{l}\text { Stage C: the crown was about half formed; the pulp } \\
\text { chamber was evident and dentinal deposition is } \\
\text { occurring. }\end{array}$ \\
\hline $\begin{array}{l}\text { Stage 4: Epiphyseal plate fully ossified, } \\
\text { epiphyseal scar visible. }\end{array}$ & $\begin{array}{l}\text { Stage D: crown formation was complete to the } \\
\text { Dentoenamel junction. The pulp chamber has } \\
\text { trapezoidal form. }\end{array}$ \\
\hline \multirow[t]{4}{*}{$\begin{array}{l}\text { Stage 5: Epiphyseal plate fully ossified, } \\
\text { epiphyseal scar is no longer visible. }\end{array}$} & $\begin{array}{l}\text { Stage E: formation of the inter-radicular bifurcation has } \\
\text { begun. Root length was less than crown length. }\end{array}$ \\
\hline & $\begin{array}{l}\text { Stage F: root length was at least as great as crown } \\
\text { length. Roots have funnel-shaped endings. }\end{array}$ \\
\hline & Stage G: root walls are parallel, but apices remain Open. \\
\hline & $\begin{array}{l}\text { Stage H: Apical ends of the roots are completely closed, } \\
\text { and the periodontal membrane has a uniform width } \\
\text { around the root. }\end{array}$ \\
\hline
\end{tabular}

Automated method based on radiographic images (Automated methods): Radiography can provide the gross stage of skeletal development. It includes Sonography, X-rays, MRI, and CT-Scans like image modalities and used to identify features of continued growth or to confirm cessation of growth in certain regions of the skeleton. These technologies are the cost effective and efficacious means of skeletal imaging. X-ray was a cost effective 2D radiographic image and used to diagnose bone disease, fractures, dislocations, tumours and in order to examine joints hand-wrist, shoulder, knee, ankle, elbow include in order of preference. A CT scan was high quality image with 360 degree image and best suited for detecting bone like medial clavicle, Radius-Ulna and Short Finger (RUS), Femur-tibia and fibula, skull fractures, upper sternal notches, examining the lungs, and detecting cancer. CT scans usually take less than five minutes or less than one minute in some cases. It was more expensive than X-ray. MRI is more detailed, high resolution cross-section images of bones, tendons, ligaments, and soft tissues like upper costal cartilages, muscle disorder. Sonography was widely available alternative to $\mathrm{X}$ ray or CT-scan medical imageries, however further limitations of sonography was objective documentation, operator dependency and examiners experience and variety in opinions makes forensic science to refer additional examinations. These radiographic methods form a potential solution to collect data and continue research in area of investigation.

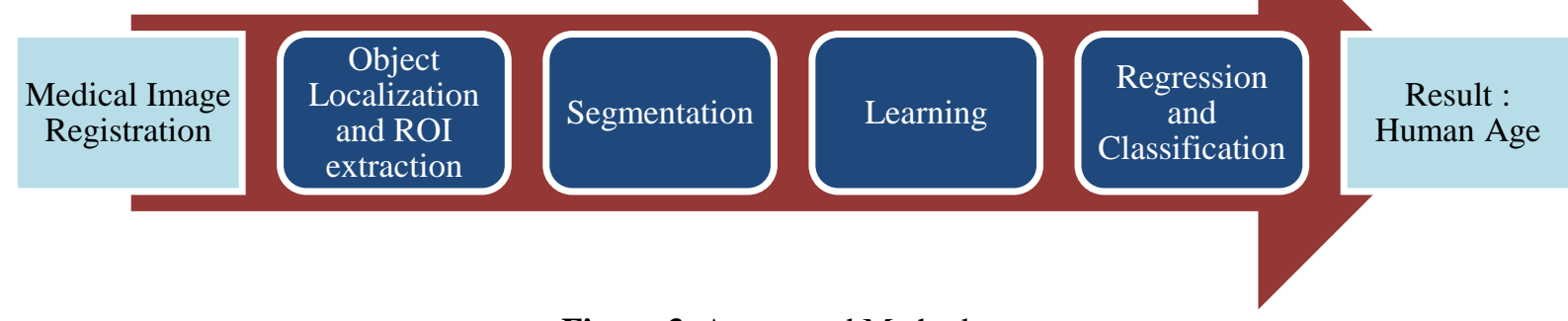

Figure 3. Automated Method 


\subsection{Evaluation of physiological Aging Features and methods}

1) Speech or voice examination: Voice is the natural identity of a person and speech is the communication media among humans. Identification of human from gender and age is interesting topic these days. Voice or speech is a physiological feature of an individual to identify a human. Many physiological changes result in voice from the childhood to adult growth because of larynx and vocal folds. Acoustic and prosodic features such as Mel Spectra with mean and Vocal Track Length Normalisation (VTLN), specific combinations of plosives and vowels, long-term features pitch and formants, jitter, shimmer, intensity, short-term frame based features such as Mel Frequency Cepstral Coefficients (MFCCs) are relatable to the physical age of the speaker. In a speech signal, Voice Onset Time (VOT) was the period between the release of a plosive and the onset of vocal cord vibrations in the production of the following sound. Voice Offset Time (VOFT), on the other hand, was the period between the end of a voiced sound and the release of the following plosive [3]. Cases such as threatening calls, false alarms, kidnapping calls can be solved with the identifying voice of a person. Age and gender identification from voice or speech helps in some complex cases. Factors affect the voice are such as surrounding environment, jitter differences, age, height, weight. Physical and psychological health status of the speaker affects a variety of physical characteristics such as the size, tension and agility of the vocal cords, the length of the vocal tract, the power and resonance of the voice source, i.e. the lungs, the size and shape of the resonant cavities, muscle response in the vocal apparatus, and many other such factors. Due to this, it is less possible to identify age from only voice of speaker $[4,5,6]$.

Table 3. Survey of voice based techniques [3-6]

\begin{tabular}{|l|l|l|l|}
\hline Work & Method/Feature used & Language & Result Analysis \\
\hline $\begin{array}{l}\text { Rita Singh et al. } \\
\text { (2016) }\end{array}$ & $\begin{array}{l}\text { Structure Prediction } \\
\text { Algorithm/ VOT \& } \\
\text { VOFT[3,4] }\end{array}$ & $\begin{array}{l}\text { American } \\
\text { English }\end{array}$ & $\begin{array}{l}\text { VOT is better than VOFT } \\
(10-85 \text { Y) }\end{array}$ \\
\hline Heerden et al. (2010) & $\begin{array}{l}\text { NN Matrix Factorization/ } \\
\text { MEL spectra and vocal } \\
\text { tract length[5] }\end{array}$ & $\begin{array}{l}\text { Dutch } \\
\text { news, } \\
\text { interviews } \\
\text { etc. }\end{array}$ & $\begin{array}{l}\text { Young (18-35Y) -38\% Middle (36-45 } \\
65 \%\end{array}$ \\
\hline $\begin{array}{l}\text { N. Minematsu et al. } \\
\text { (2002), C. Muller } \\
\text { (2003) }\end{array}$ & $\begin{array}{l}\text { SVM \& 7-class } \\
\text { classifiers/ Pitch, } \\
\text { Fomants, \& short term } \\
\text { features[6] }\end{array}$ & Germany & $46.9 \%(10-64$ Y) $)$ \\
\hline
\end{tabular}

2) Handwriting/Signature examination: Handwriting based identification restricted to certain category of writers of specific language. Very few papers were investigated on age based handwriting identification. Most of the proposed system $[7,8]$ used to predict the gender and handedness of human being. Feature descriptors such as directions, curvatures, tortuosities, chain codes, and edge-based directional features, histogram oriented gradient features, Gradient Local Binary Patterns could predict the age ranges. Handwritten text images segmented into the number of cells. Language dependency was the most important factor which affects to age estimation. Other factors are gender, left handed or right handed; databases IAM dataset and KHATT dataset, QUWI dataset 14\% handwritings were predicted age for seven different age groups. Neural Networks (NNs), Support Vector Machine (SVM), random forest as well as classifier combination methods were focused $[9,10,11,12]$.

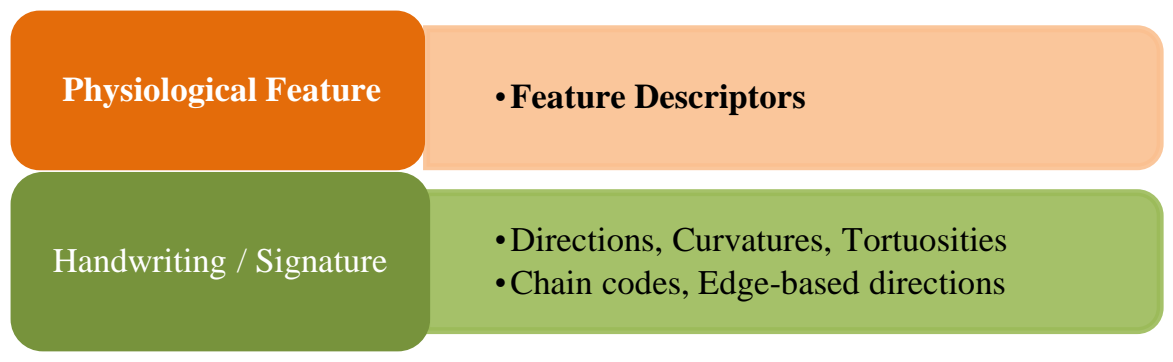


Table 4. Survey of handwriting based techniques [7-12]

\begin{tabular}{|c|c|c|c|c|}
\hline Work & Method & Dataset & Language & Result Analysis \\
\hline $\begin{array}{l}\text { C.I. Tomai et al. } \\
(2003)\end{array}$ & k-NN Classification & CEDAR dataset & English & $\begin{array}{l}\text { Binary classification - } \\
\text { under } 24 \text { years and } \\
\text { above } 45 \text { years age } \\
\text { only. } \\
\text { Accuracy }=82 \%\end{array}$ \\
\hline $\begin{array}{l}\text { K. Bandi and S.N. } \\
\text { Srihari (2005) }\end{array}$ & $\begin{array}{l}\text { FFNN and } \\
\text { combination of } \\
\text { Boosting and Bagging } \\
(\mathrm{B} \& \mathrm{~B})\end{array}$ & CEDAR dataset & English & $\begin{array}{l}\mathrm{FFNN}=82.6 \% \\
\mathrm{~B} \& \mathrm{~B}=86.6 \%\end{array}$ \\
\hline $\begin{array}{l}2007 \text { Marcus } \\
\text { Liwicki (2007) }\end{array}$ & $\begin{array}{l}\text { Binary Class SVM } \\
\text { and GMM }\end{array}$ & $\begin{array}{l}\text { IAM-OnDB - } \\
\text { Online handwriting } \\
\text { database }\end{array}$ & English & $\begin{array}{l}\text { Gender }=67.06 \% \text { and } \\
\text { handedness } \\
\text { identification }=84.66 \%\end{array}$ \\
\hline $\begin{array}{l}\text { Shubhangi D.C., } \\
\text { Dr. P.S.Hiremath } \\
(2010)\end{array}$ & Multiclass SVM & $\begin{array}{l}100 \text { handwritten } \\
\text { characters for each } \\
\text { group }\end{array}$ & English & $\begin{array}{l}1-20 \text { years }-84.54 \% \\
21-40 \text { years }-79.52 \% \\
41-60 \text { years }-80.67 \% \\
61-80 \text { years }-82.58 \\
\text { years } \\
81-100 \text { years }-90.47 \\
\text { years }\end{array}$ \\
\hline $\begin{array}{l}\text { Somaya et al. } \\
(2014)\end{array}$ & $\begin{array}{l}\text { Random Forest } \\
\text { Classifier, KDA }\end{array}$ & $\begin{array}{l}\text { QUWI dataset } \\
\text { (1017 writers) } \\
\text { (26 features) }\end{array}$ & $\begin{array}{l}\text { English and } \\
\text { Arabic both }\end{array}$ & $\begin{array}{l}\text { Age }-55 \% \\
\text { accuracy }\end{array}$ \\
\hline $\begin{array}{l}\text { Nesrine et } \\
\text { al.(2015) }\end{array}$ & SVM & $\begin{array}{l}\text { IAM-Online } 75 \\
\text { samples, KHATT } \\
\text { Dataset } 270 \\
\text { Samples }\end{array}$ & $\begin{array}{l}\text { English, } \\
\text { Arabic }\end{array}$ & $\begin{array}{l}\text { Gender }-70 \% \\
\text { Handedness }-78.57 \% \\
\text { Age under and above } 35 \\
\text { years }-<55 \% \text { accuracy } \\
\text { on KHATT samples }\end{array}$ \\
\hline
\end{tabular}

3) Gait examination: Human gait means a person's manner of walking. Generally, it shows walker's gender. Very few in literature [13-16] have worked on gait based features to estimate the human age. Gait pattern significantly changes with the advancing age. Table _ shows all papers studied are based on gender classification and age categories- children, young, elder, adult and old but not age ranges. It was observed that as gait speed decreases, the increased human age. Stride based properties, reduced velocity, shorter step length and variable increased step timings, shoulder-hip ratio and waist-hip ratio are the characteristics considered for identifying the age. Walking surface, shoes types, view side (left/right), props handled, appearance, shadows, clothing, missing body parts matters in this type of approach [15,19].

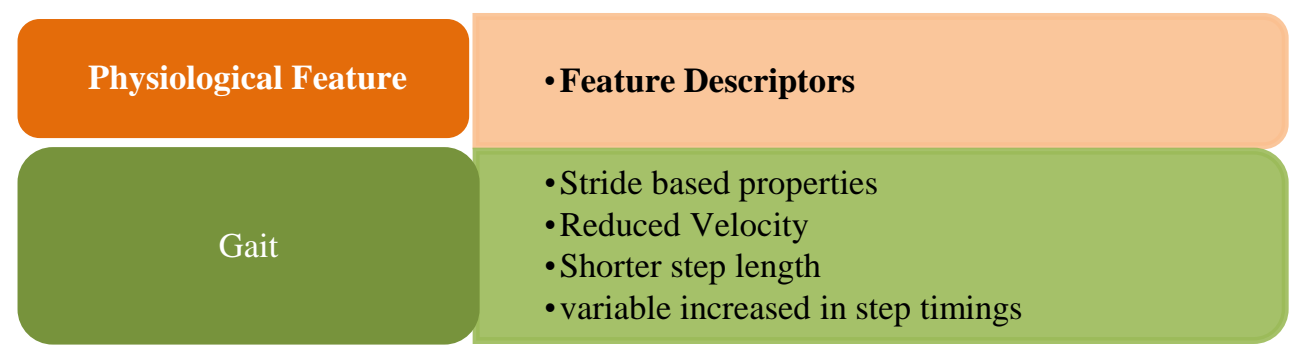


Table 5. Survey of gait based techniques [13-19]

\begin{tabular}{|c|c|c|c|}
\hline Work & Method & Age Group & Result Analysis \\
\hline J.W. Davis (2001) & $\begin{array}{l}\text { Region-growing algorithm } \\
\text { and point tracking approach }\end{array}$ & $\begin{array}{l}6 \text { - Children 3-5 yrs } \\
9 \text { - Adult 30-52 yrs }\end{array}$ & $\begin{array}{l}\text { Binary age group classification } \\
\text { on very limited dataset. } \\
\text { Accuracy }=93-95 \%\end{array}$ \\
\hline $\begin{array}{l}\text { R.K. Begg et al. } \\
(2005)\end{array}$ & SVM & Young, elder & $\begin{array}{l}\text { Binary age group classification } \\
\text { Accuracy }=83.3 \%\end{array}$ \\
\hline $\begin{array}{l}\text { Y. Makihara et al. } \\
(2010)\end{array}$ & $\mathrm{k}-\mathrm{NN}$ for Classification & $\begin{array}{l}\text { Four classes:- } \\
\text { Children, adult, } \\
\text { male and female }\end{array}$ & $\begin{array}{l}\text { Accuracy : } \\
\text { Children between } 4-15 \text { years = } \\
74 \% \\
\text { Adults between } 25-34 \text { years }= \\
91 \%\end{array}$ \\
\hline $\begin{array}{l}\text { J. Lu and Y.P. Yan } \\
(2010)\end{array}$ & $\begin{array}{l}\text { MLG subspace learning } \\
\text { and multilable k-NN }\end{array}$ & $\begin{array}{l}15-39 \text { years } \\
\text { Male, female }\end{array}$ & MAE 5.96 \\
\hline $\begin{array}{l}\text { Y. Makihara et al. } \\
\text { (2011) }\end{array}$ & $\begin{array}{l}\text { Baseline algorithm, } \\
\text { Gaussian Regression }\end{array}$ & $\begin{array}{l}\text { 2-94 years } \\
1007 \text { male and } 721 \\
\text { female }\end{array}$ & $\begin{array}{l}\text { MAE } 8.2 \text { years } \\
\text { Overestimated age }<15 \text { years and } \\
\text { underestimated age }>15 \text { years }\end{array}$ \\
\hline $\begin{array}{l}\text { Jiwen Lu et al. } \\
\text { (2014) }\end{array}$ & $\begin{array}{l}\text { Sparse reconstruction based } \\
\text { metric learning approach }\end{array}$ & & $\begin{array}{l}\text { Focused gender classification } \\
\text { only. }\end{array}$ \\
\hline
\end{tabular}

4) Face examination: Face provides perceptible information related to human trait. Among all approaches [20-30] face images are easily available evidences for the age estimation in human identification and much of work done on this feature. Social networking websites, shopping websites, matrimony websites, and criminal database images provides plenty of digital human facial images. For children and young adults, main appearance change was the shape change caused by craniofacial growth, for adults facial aging appears due to skin wrinkles and anthropometry/shape and change in texture, colour pattern. Loss in facial and muscle elasticity, wrinkles on forehead, near cheek bones and next to eyes identifies old age person. Problem in identification arises with the face alignment; sideway face, blurred face, motion face and rotation of the image, illumination variations, pose variations, facial expressions etc. Other obstacles are change in hairstyle also changes the face appearance, beard, and goggles/glasses. Simple method to tackle this problem was age synthesis i. e. generating the faces like in age progression. Sometimes it may not work due to limited training sample size data. MORPH Database, FGNET, FERNET database are most commonly used databases in recent studies. These databases directly consider age ranges/groups for age estimation. Subspace based, model based, machine learning based, image and feature driven approached are being used in the literature under computer vision category in the topic of facial aging.

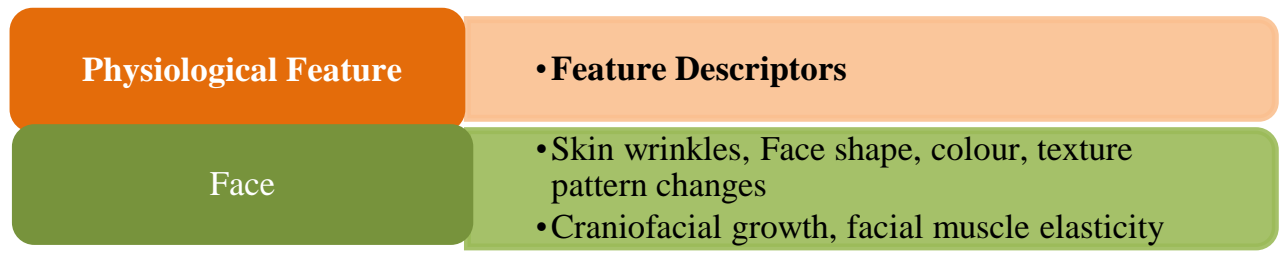

Table 6. Survey of facial image based techniques [20-30]

\begin{tabular}{|l|l|l|l|}
\hline Work & Method & Age group & Result Analysis \\
\hline X. Geng (2007) & AGES pattern Model & child and Adult & $\begin{array}{l}\text { child and Adult classification } \\
\text { MAE }=6.77\end{array}$ \\
\hline $\begin{array}{l}\text { K. Luu et al. (2009), Y. Fu et } \\
\text { al. (2010) }\end{array}$ & $\begin{array}{l}\text { Active shape Model, } \\
\text { Active Appearance } \\
\text { Model }\end{array}$ & $\begin{array}{l}\text { All ages } \\
(0-69 \text { Years })\end{array}$ & $\begin{array}{l}\text { AAM fails between youth and } \\
\text { Adults. MAE }=4.59\end{array}$ \\
\hline
\end{tabular}




\begin{tabular}{|l|l|l|l|}
\hline X. Geng (2006) & $\begin{array}{l}\text { Aging pattern Subspace, } \\
\text { Age Manifold by } \\
\text { Ordinal ranking }\end{array}$ & $\begin{array}{l}\text { All ages } \\
(0-69 \text { Years })\end{array}$ & $\begin{array}{l}\text { Many images of single person } \\
\text { used to find missing age or } \\
\text { aging images. MAE }=5.79 \\
6.49\end{array}$ \\
\hline $\begin{array}{l}\text { A. Gunay and V. V. Nabiyev } \\
\text { (2008) }\end{array}$ & $\begin{array}{l}\text { Local Binary Pattern } \\
\text { and KNN }\end{array}$ & $10-60$ Years & $\begin{array}{l}\text { Accuracy }=80 \% \text { Accuracy } \\
\text { decreases for large dataset }\end{array}$ \\
\hline $\begin{array}{l}\text { F. Gao and H. Ai (2009), H. } \\
\text { Han et al. (2015), Y.H. Kwon } \\
\text { and N.D.V. Lobo (1994) }\end{array}$ & $\begin{array}{l}\text { Gabor Filters with LDA } \\
\text { Approach }\end{array}$ & $\begin{array}{l}\text { Categories: } \\
\text { babies, young, } \\
\text { adult, old } \\
(1-50 \text { approx.) }\end{array}$ & $\begin{array}{l}\text { Accuracy }=91 \% \\
\text { Higher number of feature } \\
\text { vectors }\end{array}$ \\
\hline G. Guo et al. (2009) & Bio-Inspired Feature & 0 - 93Years & $\begin{array}{l}\text { MAE }=4.35 \\
\text { Complexity increases for cross } \\
\text { dataset }\end{array}$ \\
\hline $\begin{array}{l}\text { Dileep M R and Ajit Danti } \\
\text { (2016),Vojtech Franc and Jan } \\
\text { Cech (2017) }\end{array}$ & $\begin{array}{l}\text { Convolutional Neural } \\
\text { Networks (CNN) with } \\
\text { SVM }\end{array}$ & All ages & $\begin{array}{l}\text { Accuracy }=96.43 \% \text { Requires } \\
\text { large amount of training } \\
\text { dataset }\end{array}$ \\
\hline
\end{tabular}

\section{5) Teeth examination:}

Tooth is another physiological feature for human identification based on age. Eruption of teeth in an individual was an important part in human maturity assessment. Dental development involves several changes from childhood to death. These physiological changes in teeth can be used to derive age, gender, race like attributes of at every development stage a person. Now, with the help of various methods, dental age assessment became very easy in forensic odontology. Forensic odontology was direct or indirect application of age estimation [40]. Various tooth dimensions are measured to estimate the age with \pm 2 weeks by both methods. Best estimation could be done with vertical dimension of tooth i. e. the height of tooth. It was found that upper tooth dimensions called crown measurements such as Labio-lingual. This type of estimation is mostly done in nonadult, infants and juvenile remains in forensic laboratory. In addition with dental development and eruption, bone fusion (ossification) or skeletal maturation and size features also considered for estimating the age. Advantage of using teeth is that it may be preserved long after all other tissues, even bones. In literature, many papers have investigated on teeth.

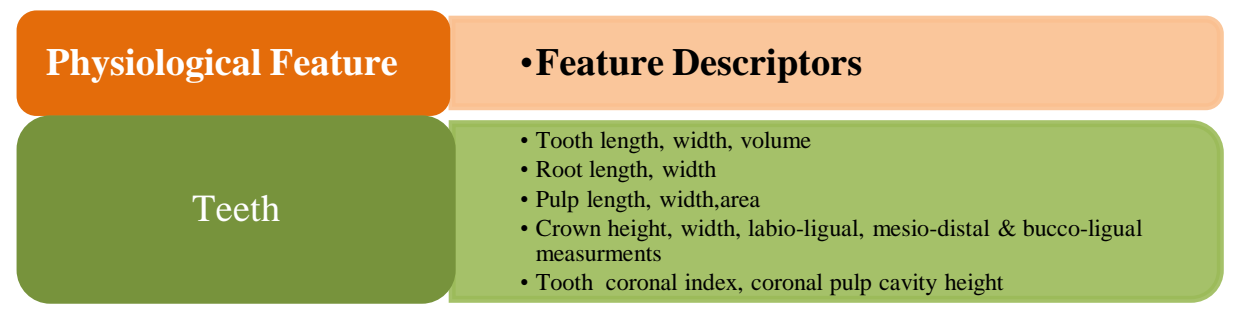

Hunt and Glesier [31] in 1955 performed age and sex assessment based on teeth and bones of children. Authors said that three kinds of estimation could be calculated on the basis of dentition that are number teeth visible in oral cavity, schedule of calcification of first molar tooth and schedule of calcification of whole dentition as per standard table 2. From these three first two estimates gives the sex of child whereas third estimate presents dental maturation stages. Due to less known information specific racial patterns of calcification of dentition, bone ossification centers were studied to estimate the human age. Author said that determination of sex was difficult from skeleton according to standards and hence if dental and bone dental ages are assessed for the skeleton by the standards of both sexes, the sex for which the standards agree best was the correct one. Later, author found proposed method impractical to estimate bone age from hand-wrist however it might be possible if applied to teeth and knee bone alone. Havvikavo in 1974 [32] selected nine teeth and investigated some reliable methods on tooth formation for six different age groups from 2-13 years. The sample set of 883 children was collected. The correlation between the mean of formation of teeth included in group age and the mean of formation of all teeth was computed for every child. The least variable teeth lower lateral and central incisor and first molar in boys and upper-lower first molars and upper first molars in girls chosen for first age group. First premolars in second, canines in third, second molars in fourth, second premolars in fifth and finally third molars in sixth age group were considered to identify teeth formation age. The correlation of $1^{\text {st }}, 2^{\text {nd }}$ and $3^{\text {rd }}$ age group 
was found from 2.5-9 years of age in children whereas $4^{\text {th }}, 5^{\text {th }}$ and $6^{\text {th }}$ from 10-13 years of age. Problem occurred to identify $6^{\text {th }}$ age group because at the age of 13 all teeth have reached to the root completed stage excluding third molar also called as Wisdom teeth. In 1976, Demirjian and Goldstein [33] had used eight stages of calcification that were observed in estimating dental maturity. Left mandibular seven teeth were focused to obtain scores and percentile standards for the age between 2-20 years. A sample set of panoramic radiographic images of 1446 boys and 1482 girls processed through 8 calcification stages ranging from calcification of the tip of tooth cusp to the closure of apex. Then sample set was increased to 2407 boys and 2349 girls who were included older and young children radiographs to overcome the drawback of earlier systems [33] that they were having less sample dataset of this maturity level and two more stages were added for first premolar and first incisor. Later authors considered four teeth system which included premolars and molars and calculated scores. When first molar was missing in older age group; central incisor was assessed as both teeth are having same development stages. Hence, other four-tooth system was considered for older age group sample which included first premolar, second molars and incisor. Score set were [33] generated by assigning one for each stage for each tooth. Addition of these scores generated maturity scores for an individual for every seven-tooth and four-tooth system. For the comparison of the seven-tooth systems the decrease was slow to about age 9 and more rapid thereafter. The standard deviations are equivalent to up to 10 months average change in maturity per year till the age of 13 years. The comparison between the seven-tooth systems show a rapid decrease in the standard deviation up to age 6 followed by a slower decrease to about age of 11years. For more accurate results author suggested that radiographs of same individual should be available with atmost one year of difference and relationship of dental maturity to skeletal maturity measures may help in further direction. Harris et al. [34] said dental development was less likely to change than the bone development as it was not affected by nutritional, endocrine and such other factors. In 1990, author compared permanent 13 tooth formation stages of Moore'set in black and white people from mid southern United States people. Author focused on only root formation stage as it starts from 3.5 years of age in children and before that crown formation was there. Results from stages 1 to 11 found that the mean difference for root formation was observed as 0.5 years in whites and 0.3 years in blacks and in females begin and complete tooth formation earlier than males. Team of Kvaal et al. [35] proposed analysis of teeth on radiographs of the all teeth of people aged between 20-87 years using ten measurements. Ratio between length of pulp and root $(\mathrm{P})$, Ratio between tooth and root length $(\mathrm{T})$, Ratio between pulp and tooth length $(\mathrm{R})$, Ratio between width of pulp and root at enamel-cementum junction (A), Ratio between pulp and root width at midpoint between $\mathrm{C}$ and A (B), Ratio between pulp and root width at mid-root level (C), Mean value of all ratios (first predictor) $(\mathrm{M})$, Mean value of width ratios from levels $\mathrm{B}$ and $\mathrm{C}(\mathrm{W})$, mean value of the length ratios $\mathrm{P}$ and $\mathrm{R}(\mathrm{W})$ and the difference between $\mathrm{W}$ and $\mathrm{L}$ (Second predictor) measurements were calculated by two observers as shown in fig. 4. PCA of the predictors was performed and then regression analysis was applied. Author investigation found that ratio between tooth to root length was incompatible for all teeth and could not be related to age where as ratio of pulp to root length were significant and same stronger correlation was found with the mean of all the ratios with the age. It was also concluded that information from all types of teeth gives more correct age estimation than a single tooth. In previous studies, authors had used to only observe the dental development stages using manual methods using teeth extraction and destruction approach as it requires manual cross-sections of teeth. Some authors had used radiographic image based approaches for observation and calculated the dental age manually. These methods are very time consuming, observer specific, expensive and they may not be acceptable for ethical, religious, cultural, or scientific reasons. Cameriere et al. [36] in 2004 proposed a method for age estimation based on ratio of pulp to tooth area on single rooted teeth using stepwise multiple regression analysis. X-rays of canines of 100 Caucassian patients aged between 18-72 years were digitized using scanner for image analysis. Images are processed using AutoCAD2000 program and region of interest i.e. tooth and pulp area were identified.

Table 7. Survey of tooth/teeth image based techniques [31-41]

\begin{tabular}{|l|l|l|l|}
\hline Authors/year & Method\& Tooth/teeth used & Age range & Result Analysis \\
\hline $\begin{array}{l}\text { Gleiser and Hunt, } \\
(1955)\end{array}$ & $\begin{array}{l}\text { Manual method/ First molar and } \\
\text { bones }\end{array}$ & Children & $\begin{array}{l}\text { Compared teeth and bone } \\
\text { assessment for gender and age } \\
\text { estimation }\end{array}$ \\
\hline Haavikko, (1970) & $\begin{array}{l}\text { Manual method/9 teeth: Premolars, } \\
\text { molars and incisors }\end{array}$ & $\begin{array}{l}\text { 2-13 years } \\
\text { Problem occurred when tooth } \\
\text { formation completed at the age } \\
\text { of 13 years as all teeth root } \\
\text { formation completed. }\end{array}$ \\
\hline $\begin{array}{l}\text { Demirjian } \\
\text { \&Goldstein., (1973 } \\
\& \text { 1976) }\end{array}$ & $\begin{array}{l}\text { Manual method/7 teeth: Premolars } \\
\text { and molars }\end{array}$ & 2-20 years & $\begin{array}{l}\text { Found most accurate results } \\
\text { compare to others from 1955- } \\
1992\end{array}$ \\
\hline $\begin{array}{l}\text { Harris and McKee, } \\
(1984)\end{array}$ & Manual method/ All teeth. & $\begin{array}{l}\text { From 3.5 years to } \\
\text { crown formation }\end{array}$ & $\begin{array}{l}\text { Tooth formation 0.5 in males and } \\
\text { 0.3years in females earlier. }\end{array}$ \\
\hline
\end{tabular}




\begin{tabular}{|c|c|c|c|}
\hline & & age & \\
\hline Kvaal et al. (1995) & $\begin{array}{l}\text { Semi-automated method: PCA based } \\
\text { regression analysis and manual } \\
\text { observation of radiographs for } \\
\text { measurements/ X- ray of all teeth }\end{array}$ & 20-87 years & $\begin{array}{l}\text { Instead of focusing on single } \\
\text { tooth, all types of teeth could be } \\
\text { taken into consideration. }\end{array}$ \\
\hline $\begin{array}{l}\text { R. Cameriere et al. } \\
(2004)\end{array}$ & $\begin{array}{l}\text { Semi-automated method: First time } \\
\text { digital image of an X-ray using } \\
\text { scanner/ Scanned X-ray digital image } \\
\text { of canines }\end{array}$ & $\begin{array}{l}100 \text { Caucasian } \\
\text { patients between } \\
18-72 \text { years }\end{array}$ & $\begin{array}{l}\text { Instead of focusing on single } \\
\text { tooth, all types of teeth could be } \\
\text { taken into consideration. }\end{array}$ \\
\hline $\begin{array}{l}\text { R. Cameriere et al. } \\
(2007)\end{array}$ & $\begin{array}{l}\text { Automated method/ Peri-apical x-rays } \\
\text { of upper and lower canines }\end{array}$ & $\begin{array}{l}100 \text { Caucasian } \\
\text { patients between } \\
18-72 \text { years }\end{array}$ & $\begin{array}{l}\text { Projection from all sides could } \\
\text { provide better results. }\end{array}$ \\
\hline $\begin{array}{l}\text { Hala Mohmed } \\
\text { Ahmed et al. } \\
(2013)\end{array}$ & $\begin{array}{l}\text { Automated method/ Multiplanner } \\
\text { slices of image incisors, canines and } \\
\text { premolar }\end{array}$ & -- & Accuracy $=97 \%$ \\
\hline $\begin{array}{l}\text { R. Cameriere et al. } \\
(2014)\end{array}$ & Automated method/ X-rays & $\begin{array}{l}100 \text { Caucasian } \\
\text { patients between } \\
18-72 \text { years }\end{array}$ & Loss of data due to Segmentation \\
\hline $\begin{array}{l}\text { Aka P. Sema et al. } \\
(2014)\end{array}$ & Manual method/ All teeth & $\begin{array}{l}\text { Infants aged } \\
\text { between 1-195 } \\
\text { weeks }\end{array}$ & Accuracy $=+/-0-2$ weeks \\
\hline Nagi R. (2019) & $\begin{array}{l}\text { Automated method/ Premolars and } \\
\text { molars }\end{array}$ & 100 subjects & $\begin{array}{l}\text { Second molar is more reliable } \\
\text { and tooth coronal index is } \\
\text { reliable marker }\end{array}$ \\
\hline
\end{tabular}

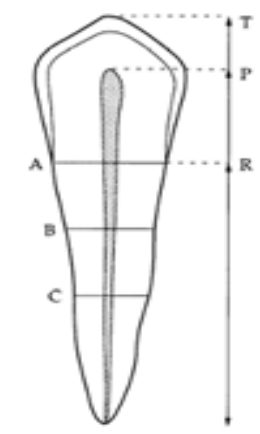

Figure 4. Kvaal et al. method [35]

All measurements were carried out by different observers and correlation confidents were calculated. Pearson's correlation coefficients showed significant correlation with the age. In previous study, author had used peri-apical X-rays. Peri-apical X-ray shows the bite wing, whole tooth-from crown to beyond the root where the tooth attaches into either upper or lower portion of jaw. In 2007, [37] author worked on labio-lingual and periapical X-rays of upper and lower canines as they could give more information for combined analysis. All measurements are carried out to obtain the results. Results yielded significant improvement with the accuracy of the method $\mathrm{ME}=2.8$ years by considering both upper and lower canines. Two different projections, labio-ligual and peri-apical x-rays provided large amount of information which lead to accurate estimation. However, the method could not avoid the bias that was inherent in the subjectivity of the observer. Projections from all sides may provide larger data as in CT-scan but it was usually impossible to apply. Later, Cameriere et al.[37, 39] performed automatic age estimation for adults from radiographic images in 2014. The proposed algorithm was the same method that was based on automatic image processing techniques such as conversion into grey scale image, segmentation, filtering then selecting region of interest and calculating the measurements. Problem occurred when segmentation method lead in reduction of pulp area computed which provided the new Cameriere's formula that had used pulp to tooth volume ratio instead of ratio of pulp to tooth area. The new Cameriere's formula gave same results as obtained by observers. Faculties of Dentistry of Minia University, Egypt, Hala Mohmed Ahmed et al. [38] had studied Cone Beam CT (CBCT) images in 2013 year. Total 48 cases were studied and pulp, tooth and root measurements are derived from CBCT images of right upper incisors, canine and premolar. Three-dimensional CT-scan application software calculated required measurements automatically by dividing multi-planner slices of images. The data were collected, statically analyzed and correlation coefficients were calculated. The best accurate model was detected $97 \%$ accuracy in correlating 
identified age with chronological age. The model was generated by sum of pulp length, crown width with pulp width respectively at the mid level of pulp of upper first premolar. Second more accurate model was detected $96 \%$ accuracy in upper central incisor with the measurement of pulse width at the mid level of pulp in buccolingual (BL) dimension. Aka P. Sema et al. (2014) [40] introduced new novel method using CT-Scan in forensic age estimation for deciduous teeth (Primary/milk teeth). Both direct and indirect measurements of upper central incisor tooth of infants aged between $1-195$ weeks was considered. Tooth was extracted and direct crown measurements labio-lingual (LL), mesio-distal (MD), and tooth height (TH); crown height (CH), root height (RH), and crown thickness (CrT) were recorded by Digital Vernier compass and dental metal thickness compass respectively. Indirect measurements are recorded from CT-Scan sagittal, coronal, and axial planes for each central incisor. It was found that tooth height which was a longest vertical dimension provided best accuracy with margin of error (ME) $\pm 0-2$ weeks in age estimation. Regression formulas were generated using regression analysis for tooth height as follows.

Direct Method: $\operatorname{Ln}($ Age $)=3.130-0.061 \times \mathrm{Sex}+0.096 \times \mathrm{TH}+0.009 \times \mathrm{Sex} \times \mathrm{TH}$

Indirect Method: $\operatorname{Ln}($ Age $)=0.264+0.049 \times \mathrm{CT}$ Axes+0.341 $\times$ TH-0.006 $\times$ CT Axes $\times \mathrm{TH}$

Nagi et al. (2019) [41] used computerized panoramic radiographs of premolars and molars data of 100 subjects for statistical analysis in dental age estimation. Author preferred to calculate Tooth Coronal Index (TCI) and observed that it was decreasing with advancing age and highly negative correlation for second premolar ( $\mathrm{r}=-$ $0.168)$ and first molar $(\mathrm{r}=-0.0092)$. It indicated that second premolar as more reliable indicator and TCI as more reliable marker for age estimation. TCI was calculated as:

$\mathrm{TCI}=\mathrm{CPCH} * 100 / \mathrm{CH}$

$\mathrm{CH}=$ Coronal height measured vertically straight from the cervical line to the tip of the highest cusp.

$\mathrm{CPCH}=$ Coronal pulp cavity height measured vertically from the cervical line to the tip of the highest pulp horn. (Fig. 5)

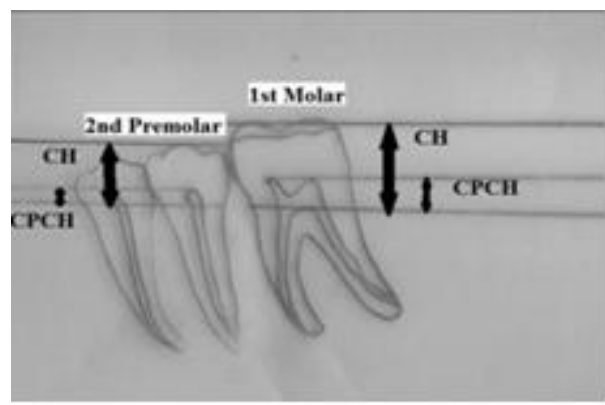

Figure 5. Nagi et al. method [41]

\subsection{Evaluation of Biological Features and methods}

1) Whole blood and DNA examination: Blood is one of the most often encountered and valuable traces found at a crime scene. CpG methylation and DNA methylation markers were utilised to indicate aging from blood. Recent studies [42-43] showed that aging process is highly related to change in CpG and DNA methylation patterns. Raman spectroscopy [42] was successful in species identification and blood aging under laboratory conditions. The proposed spectral processing model [43] assumes a homogeneous blood stain with a constant thickness. These assumptions cause some deviations when compared to the reflectance spectrum measured in reality because of non homogeneity of thickness. Haemoglobin derivatives such as $\mathrm{HbO} 2, \mathrm{MetHb}$ and $\mathrm{HC}$ fraction measurements in blood stains considered as a function of time to estimate the age. Colour of blood changes from red to dark brown factors that affects in whole blood age estimation. The accuracy of age estimates decreases with the age of the blood stain. Thus, to determine small differences in age, spectroscopic measurements should be performed as soon as possible after the crime. Environmental circumstances, humidity and temperature influence the speed of the chemical reactions within blood stains. It is found that blood cannot give human age but bloodstains age.

\section{2) Fingerprint examination:}

Fingerprint is a biological marker for human identification. Gender and age estimation adds a new research domain to fingerprint. Basic fingerprint pattern remains same while size and shape of fingerprint varies from infant to old age. Morphological features such as ridges, valleys, thickness, size or amount of pores, curvelet domain are the main area in fingerprint based estimation. As there is no accurate age and gender estimation in fingerprint domain for human identification, very less papers [44-48] are observed on fingerprint and study done 
for finding mostly the age groups of children, young and adults. Latent fingerprint features extracted are binary pixels, mean pixel, standard deviation. Problems faced in healing stages of wounds on fingers, luminescence behaviour, degradation using chemical methods, chromatography, mass spectrometry and various surface types. Smooth, plain, non-porous and well reflecting surfaces like mirrors, glass, displays could give nearly accurate results.

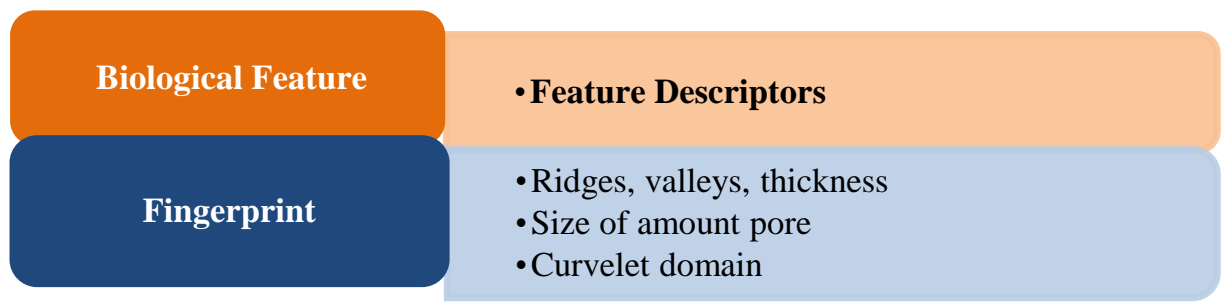

3) Iris examination: Iris is another biological feature that provides perceptible information. People from different race may have different iris pattern. Some people may have bright and colourful with clear texture and some may show dark or brown from which it is impossible to obtain detailed texture with naked eye. Iris texture features such as Gabor energy, statistics of spot and light filters and Scale Invariant Feature Transform (SIFT) are popular mostly in finding out gender, race information from group of people. Geometric features describing iris dimension had also been used in the literature studies [49-52].

Table 8. Survey of iris based techniques [49-52]

\begin{tabular}{|c|c|c|c|}
\hline Work & Method & Dataset & Result Analysis \\
\hline Xianchao Qiu et al. (2007) & SVM & $\begin{array}{l}\text { CASIA Bio-secure dataset } \\
\text { of } 2400 \text { iris samples }\end{array}$ & $\begin{array}{l}\text { Race and ethnicity prediction of } \\
\text { Asian and non-Asian people } \\
\text { Accuracy }=91.02 \%\end{array}$ \\
\hline $\begin{array}{l}\text { Stephen Lagree and Kevin } \\
\text { W. Bowyer (2011) }\end{array}$ & $\begin{array}{l}\text { SMO } \\
\text { SVM }\end{array}$ & $\begin{array}{l}600 \text { iris images } \\
60 \text { Asian male-female } \\
60 \text { Caucasian male-female }\end{array}$ & $\begin{array}{l}\text { Gender and ethnicity prediction of } \\
\text { Asian and Caucasian people } \\
\text { Accuracy: Gender }=62 \% \\
\text { ethnicity }=90.58 \%\end{array}$ \\
\hline Atul Bansal et al. (2012) & $\begin{array}{l}\text { DWT and } \\
\text { SVM }\end{array}$ & 300 images & $\begin{array}{l}\text { Gender Classification } \\
\text { Accuracy }=83.06 \%\end{array}$ \\
\hline $\begin{array}{l}\text { Juan Tapia Farias and } \\
\text { Claudio Perez }(2014)\end{array}$ & LBP & UND iris Dataset & $\begin{array}{l}\text { Gender Classification } \\
\text { Accuracy }=91.00 \%\end{array}$ \\
\hline
\end{tabular}

\section{4) Human skeleton examination}

a. Hand-wrist examination: In earlier days, radiologists observed the bone growth indicators as maturity parameters. Based on bone ossification measures, in 1926, Carter [53] observed growth pattern of carpal bones of hand-wrist and said that are very irregular in shape. Diameter measurement could not provide the degree of accuracy instead suggested that planimeter could be used for measurement of the circumscribed area of bone. Eight carpal bones and epiphysis of radius ulna was measured using planimeter. Although variations are present partly due to size of bones and partly due to maturation of hand the ratio of total ossification to carpal quadrilateral was calculated and concluded that the measurement method was more reliable than inspection or observation method. In 1928, Garside and Helen [54] had studied anatomic growth in children. Examination was carried out on 1300 roentgenograms of hand-wrist and forearms. Quantitative measure of circumscribed area of each carpal bone was measured with planimeter. In the first inspection, it was observed that girl for ages 8-12 years children were in advance than of boy for ages 10-16 years children and there was greatest correlation between total carpal area and physical traits such as height, width, width of shoulders and width of hips. In 1950 , Greulich and Pyle (G\&P) [55] published radiographic atlas for left hand hand-wrist skeletal development. Gender oriented atlas categorised into different age groups. G\&P used simple and faster method. 


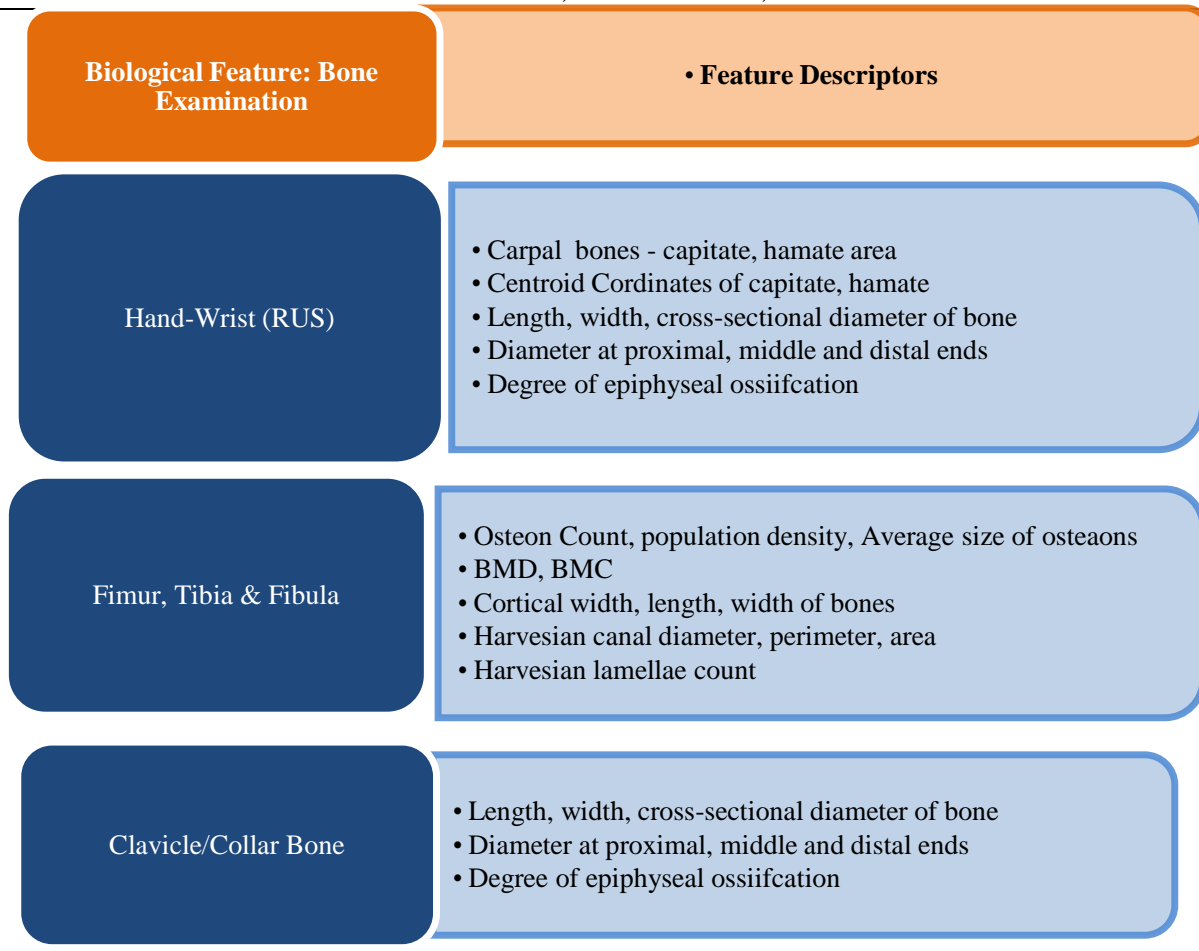

Table 9. Survey of Hand-wrist based techniques [53-78]

\begin{tabular}{|c|c|c|c|}
\hline Authors/year & Method \& bone used & Age Group & Result Analysis \\
\hline \begin{tabular}{|ll} 
Garside and \\
Helen (1928)
\end{tabular} & $\begin{array}{ll}\text { Manual method/ Hand } \\
\text { radiograph }\end{array}$ & 8-16 years & $\begin{array}{l}\text { Relation between carpal area } \\
\text { and height was measured. }\end{array}$ \\
\hline \begin{tabular}{|l} 
Greulich and \\
Pyle \\
$(1950,1959)$ \\
\end{tabular} & $\begin{array}{l}\text { Manual method/ Radiographic } \\
\text { films of hand wrist (1931- } \\
1942)\end{array}$ & $0-18$ years & \\
\hline $\begin{array}{lr}\text { Tanner r and } \\
\text { Whitehouse } \\
\text { (1975a) }\end{array}$ & Manual method/ RUS X-ray & $1-21$ years & $\begin{array}{l}\text { Maturity of Selected skeletal of } \\
\text { hand wrist X-ray determined }\end{array}$ \\
\hline TW2 (1975b) & $\begin{array}{l}\text { Manual method/ RUS X-rays } \\
(1946-1970)\end{array}$ & $1-21$ years & $\begin{array}{l}\text { According to age, height was } \\
\text { measured }\end{array}$ \\
\hline $\begin{array}{l}\text { Roche et al. } \\
\text { FELS } \\
(1988)\end{array}$ & $\begin{array}{l}\text { Manual method/ Hand wrist } \\
\text { X-rays (1932-1977) }\end{array}$ & Below 15 years & $\begin{array}{l}\text { longer a characteristic could be } \\
\text { detected in the maturation } \\
\text { process, the less information it } \\
\text { provides }\end{array}$ \\
\hline $\begin{array}{l}\text { Michael and } \\
\text { Nelson (1989) }\end{array}$ & $\begin{array}{l}\text { HANDX system/ Semi- } \\
\text { automated method / third distal } \\
\text { phalange bone }\end{array}$ & Below 15 years & $\begin{array}{l}\text { Comparison of two children } \\
\text { hands, Observer variability } \\
\text { reduced but with no reasonable } \\
\text { Accuracy. }\end{array}$ \\
\hline \begin{tabular}{|lr} 
Pietka & and \\
Michael et al. \\
$(1991)$
\end{tabular} & $\begin{array}{l}\text { Automated PROI-based system } \\
\text { / proximal, middle and distal } \\
\text { phalanx of third finger }\end{array}$ & Below 20 years & Evaluated in small scale \\
\hline $\begin{array}{l}\text { Hill and } \\
\text { Pynsent } \\
(1994) \\
\end{array}$ & $\begin{array}{l}\text { TW2 based Automated method } \\
\text { /20 RUS bones }\end{array}$ & Not specified & $\begin{array}{l}\text { Small group of sample images } \\
\text { Error rate was about } 0.5 \text { years }\end{array}$ \\
\hline $\begin{array}{l}\text { Gross et al.. } \\
(1995)\end{array}$ & $\begin{array}{l}\text { Neural network system based } \\
\text { on linear/ Based on linear } \\
\text { distance measures }\end{array}$ & Below 20 years & $\begin{array}{l}\text { Did not use morphological } \\
\text { Feature }\end{array}$ \\
\hline $\begin{array}{l}\text { Rucci et al.. } \\
(1995)\end{array}$ & $\begin{array}{l}\text { Neural network analysis based } \\
\text { on the epiphyses and carpal/ } \\
\text { Based on the TW method and } \\
\text { using the epiphyses and carpal }\end{array}$ & 2-16 years & $\begin{array}{l}\text { Neural network system started } \\
\text { in } \\
\text { dumb state Error rate was about } \\
0.7 \text { years }\end{array}$ \\
\hline Sato et al.(1999) & $\begin{array}{l}\text { Regression analysis, The third } \\
\text { finger-three } \\
\text { metaphysic Analyzing the } \\
\text { bones of the third digit/80-90 }\end{array}$ & \begin{tabular}{|lr}
$80-90 \%$ on each phalanx, \\
Found & significant \\
correlation & between \\
epiphyseal & width and
\end{tabular} & $\begin{array}{l}\text { Covered the children between } 2 \\
\text { and } 15 \text { years Poor image } \\
\text { processing techniques }\end{array}$ \\
\hline
\end{tabular}




\begin{tabular}{|c|c|c|c|}
\hline & $\begin{array}{l}\% \text { on each phalanx Scanned } \\
\text { images of } x \text {-ray films }\end{array}$ & metaphseal width & \\
\hline $\begin{array}{l}\text { Mahmoodi } \\
\text { et al.. } \\
(2000)\end{array}$ & $\begin{array}{l}\text { Mahmoodi model } \\
\text { Analysis phalangeal and } \\
\text { active shape model }\end{array}$ & Below 20 years & $\begin{array}{l}\text { Bone age accuracies of } \\
(82 \pm 3) \% \text { for males and } \\
(84 \pm 3) \% \text { for females }\end{array}$ \\
\hline $\begin{array}{l}\text { Pietka et al.. } \\
(2005)\end{array}$ & $\begin{array}{l}\text { Phalanges length based system/ } \\
\text { Segmentation of phalangeal } \\
\text { length or carpal }\end{array}$ & Below 20 years & $\begin{array}{l}\text { Error rate was roughly } 1 \text { year, } \\
\text { Depends on the reference } \\
\text { population group }\end{array}$ \\
\hline $\begin{array}{l}\text { Cameriere et al. } \\
(2006)\end{array}$ & $\begin{array}{ll}\text { recent } & \text { application } \\
\text { planimetric } & \text { principles }\end{array}$ & $5-17$ years & $\begin{array}{l}\text { The ratio of the Carpal area and } \\
\text { the total area of carpal bones } \\
\text { and Epiphyses of the ulna and } \\
\text { radius was determined. }\end{array}$ \\
\hline $\begin{array}{l}\text { Hsieh et al. } \\
(2007)\end{array}$ & $\begin{array}{l}\text { Phalanges, epiphyses, and } \\
\text { carpals/ Based on phalangeal } \\
\text { region of interest (PROI) }\end{array}$ & Below 15 years & $\begin{array}{l}\text { The accuracy was evaluated to } \\
\text { be } 85 \% \text {. } \\
\text { Poor image processing } \\
\text { techniques }\end{array}$ \\
\hline Liu et al. (2008) & $\begin{array}{l}\text { NN classifiers using RUS and } \\
\text { carpal/ Based on RUS and } \\
\text { carpal bones }\end{array}$ & 2-26 years & High image processing loading \\
\hline $\begin{array}{l}\text { Thodberg et al. } \\
\text { (2009) }\end{array}$ & $\begin{array}{l}\text { BoneXpert Method/ AAM } \\
\text { model }\end{array}$ & 2-17 year & Carpal bones unaddressed. \\
\hline $\begin{array}{l}\text { Marco Tise et al. } \\
(2011)\end{array}$ & $\begin{array}{l}\text { Validity of G\&P method on } \\
\text { Italian people }\end{array}$ & $\begin{array}{l}\text { Below and equal to } 18 \\
\text { years }\end{array}$ & $\begin{array}{l}\text { Wide margin of error at } 14 \text { and } \\
18 \text { years legal ages. }\end{array}$ \\
\hline $\begin{array}{l}\text { Somkantha et al. } \\
(2011)\end{array}$ & SVR and NN & 0-6years & SVR is better than NN \\
\hline $\begin{array}{l}\text { Mansourvar et al. } \\
(2012)\end{array}$ & Histogram based Model, CBIR & $0-18$ years & $\begin{array}{l}-0.17 \text { error rate in comparison } \\
\text { with BoneXpert Method }\end{array}$ \\
\hline Stern et al.(2016) & $\begin{array}{l}\text { Fully automated G\&P method } \\
\text { using NN }\end{array}$ & 6-11.9 years & $\begin{array}{l}\text { Large error between G\&P } \\
\text { manual and proposed metod. }\end{array}$ \\
\hline $\begin{array}{l}\text { Neumayer et al. } \\
(2018)\end{array}$ & $\begin{array}{l}\text { Medical image reconstruction } \\
\text { using TGV method }\end{array}$ & Below 15 years & Automated Urschler method \\
\hline Erik et. al (2020) & $\begin{array}{l}\text { Automated method using R- } \\
\text { CNN/ RUS bines }\end{array}$ & Infant -19 years & MAE $=1.007$ years \\
\hline
\end{tabular}

Results are considerably variable according to observers training and experience. Tanner Whitehouse (TW) method was scoring method [56, 57] developed in 1962 based on hand-wrist of an individual between 1 to 21 years of age. Maximum 20 individual bones are studied in hand-wrist and their different combinations of radius, ulna, and selected metacarpals. This method cannot be applied for every individual because of verity of population like Japanese, Chinese, and German etc. The study of medial clavicle [44-46] concentrates on radiographic data and Computed Tomography (CT) scans. In application of Schemeling method anterior and posterior radiographic imaging of medial clavicle was carried out at fusion stage. With the help of CT, it was concluded that medial clavicle was valid means of determining the minimum age in legal cases. This type of approach mostly used in adult upto 40years age. It was very difficult in senior or older age adults between 60$80 y e a r s$ by traditional method because of missing or decaying the bone information. TW2 method height was predicted on basis of bone age. Bone age was calculated by TW1 method. In comparison with G\&P method, TW method was more accurate and reliable as it uses systematic evaluation in terms of numeric score united with growth stages. The sum of all 20 scores of ROI of individual bone was used to estimate the age group. In 1988, Roche et al. [58] defined automated Fels Longitudinal Study (FELS) method which describes progression of maturity indicators and grades calculations. The method was compared with past Tanner-Whitehouse (TW) and G\&P where it was observed that FELS method was consistently ahead of TW method for below 15 years in both the sexes (boys and girls) / more appropriate method for United States children and adolescence and concluded that as longer as a characteristic could be detected in the maturation process, the less information it provides. In 1989, Michel and Nelson [59] used semi-automated system. The authors divided the system into three stages for medical image processing- Pre-processing, Segmentation and Measurements. Model based Histogram modification was used for pre-processing. The third distal phalange bone of hand had been focused as object(s) of interest in segmentation process. Then measurement values of Hand 1 and Hand 2 are calculated by the system. No reasonable accuracy was found in the proposed system. In 1991, Pietka and Michael et al. [60] 
presented paper on skeletal maturity using paediatric radiology. The automated approach used computed radiography for the first time in skeletal maturity assessment. Phalangeal Region of Interest (PROI) was searched and threshold sobel gradient image was created to find edges of bones and epiphyses and then skeletal age was obtained by measuring the length of proximal, middle and distal phalanx of third finger and comparing with standard tables. Results give the direction to apply more complex methods in order to indicate skeletal maturity. More morphological features needs to be includes than only phalangeal length. In 1994, Hill and Pynsent [61] presented fully automated system for radiographic images. In the system, features are classified according to TW2 method. Bones are recognized by landmarks using pattern recognisation. Fuzzy grammars used to identify shape and type of arcs of a bone. Three options provided are TW2 RUS 13 bones, 7 carpal bones and total 20 bones to identify ages in 4 minutes without human intervention to avoid intra-observer error. In 1995, Gross et al. [62] used Neural Network (NN) method. The investigation was to demonstrate NN and could be used to determine skeletal maturity. It gave large variations between NN method and radiologist observations. Because only four features had been used in NN method whereas radiologist used large number of features in hand radiographs.

According to TW method, NN method gave larger variation in results but surprisingly much better with G\&P atlas method in children. In Same year 1995, Rucci et al. [63] has used Artificial Neural Network (ANN). The system uses two modules. One was Attention Focuser (AF) and other was Bone Classifier (BC). AF identified landmark to localise bones and BC was used for ANN based classifier modules. Classifier module classifies bone by generating vector of bone maturity indicators. Vector of bone maturity indicators are calculated using TW2 20 number of bone of hand-wrist. Supervised learning was carried out by means of back propagation algorithm. The results suggest that the behaviour of proposed system was similar to medical/ subject experts. In 1996, Z. Liu and Austin et al. presented quantitative analysis of microstructural features of cross sections of human bones. In this system, digital image processing techniques are used to extract features that provide reliable statistical data of bones. Bone features like number, area, circumference of primary and secondary osteaons and osteaon fragments are calculated. In 1999, Sato et al. [64] proposed an automated system to overcome weak points of TW2 method. The focus was given on the third finger epiphyseal and metaphyseal and overlapping widths of distal, middle and proximal phalanges. Skeletal maturity was assessed by multiple regression analysis with from the scanned image of hand-wrist x-ray of 318 healthy Japanese boys and 199 girls in the age range 2 to 15 years. The results are not so accurate because of overlapping widths of under maturation bones. But the method shows significant correlation between chronological age and the ratio of epiphyseal and metaphyseal width. In 2000, Sasaan Mehmoodi [65] reported an automated knowledge based vision system for assessing skeletal maturity. Dataset of hand-wrist images of 32 boys and 25 girls aged between 1-16 years was used. Three bone shape contour descriptors Principal Component Coefficients (PCC), proximal part of phalanx - Shape Moments (MOM) and Epiphysis width to Metaphysis width Ratio [EMR] as a feature vector [PCC, MOM, EMR] was obtained from Active Shape Model (ASM) segmentation. Bayesian principal applied on these descriptors.

Authors reported $63 \%$ and $75 \%$ accuracy using the proposed method based on carpal and phalanx regions respectively. The skeletal maturity was obtained from the training set. In 2005, Pietka, Gertych and Witko [66] implemented Computer Aided Diagnosis (CAD) system with same three layers discussed earlier in this paper as image manipulation, Anatomical region/features extraction and medical abnormality extraction. The CAD system was helpful in medical training, teaching and clinical application to assist radiologist. Adaptive segmentation with hierarchical multiresolution approach was used in segmentation. 2-4 middle and distal phalanx regions are located to generate eleven elements feature vector. A decision making process based on fuzzy logic/rules in feature analysis and classification solves the problem of replicability. $70 \%$ cases found with less than 1.5 years difference between bone age and chronological age whereas 4.5 cases exceeded 3 years difference. In 2006, Cameriere R. et al., [67] Biological growth was measured using X-ray images of Hand-wrist for personal identification. The study carried out on 150 Italian Children and adolescents (89 boys and 61 girls) aged between 5 to 17 years. The carpal area was selected using the polygonal lasso instrument of Adobe Photoshop 7 software and computed pixels by CAD. Histogram was presented to generate global values of bone areas. Common area was determined for the overlapping bones and the total area of carpal bone to epiphyses of radius and ulna ratio was calculated and used for linear regression analysis.

The standard error of 1.19 years was estimated in the obtained results. It was suggested that in addition with carpal bones, tooth growth information may provide better results. After 1995, again NN was used with fuzzy logic by Chi-Wen Hsieh in 2006 [68]. Basically, the skeletal maturity assessment especially for carpal bone was based on the analysis of carpal bone area, number of carpal bones and shape. Unfortunately, some carpals may overlap with others as growth proceeds, and thus it was more difficult to make an assessment of skeletal age for people from 10 years old to adult stage. In the stage of development, the phalanx's analysis produces more reliable estimation results. The proposed system combined carpal and phalanxes maturity assessment. 
Quantitatively physiological and morphological features are measured. Principle Component Analysis (PCA) was used to map raw data into hyperplane. Back Propagation (BP), Radial Basis Function (RBF), Support Vector Machine NN (SVMNN) are used to assess the proposed system and recommended SVMNN as best choice to estimate skeletal maturity. Dataset of 713 children (358 females and 355 males) in age range 0.5 to 18years old $\mathrm{X}$-ray images was used. The survey also found that the classification rates in female database are slightly better than those in male case. In 2007, Zhang [69] described fully automatic carpal bone segmentation and feature analysis method. Carpal bone ROI was extracted and smoothed out using anisotropic diffusion filter to remove background noise and preserving edges at the same time. ROI contours are extracted by canny edge detector and features are analysed. Then final results are obtained by fuzzy classification technique. The ROI reliability was observed between 0-5 years, 6-12 years and 13-18 years age group for both genders for phalangeal and carpal ROI. It was proved that feature extraction was more reliable in size and shape analysis of carpal bone ROI ages between 0-7 years before the start of overlapping carpals in young children. It was more reliable in size and shape analysis of epi-metaphysis in phalangeal ROI between ages between 6-12 years and highly reliable in degree of fusion of epi-metaphysis between ages 13-18years.

In 2008, Jian Liu et al. [69] developed an automated system using ANN and new optimization method Particle Swarm Optimization (PSO) on 1046 digital X-ray Radiographs aged between 0 to 18 years. The objective to introduce PSO was to surmount the drawbacks of ROI segmentation and shape recognisation. 13 Radius, Ulna and Short finger (RUS) and 7 carpal bones in comparison with TW3 method. In experimentation process it was found that manual reading has higher standard deviation than the proposed method but variations are comparatively larger in RUS than carpal bone assessment under the age of 9 years. In the same year, Antonio Tristan-Vega and Juan Ignacio Arribas [70] had performed detailed analysis of radius and ulna wrist bones. Semiautomatic adaptive clustering segmentation algorithm was used to mark the shape of bones. 89 features were extracted for bone assessment in feature extraction process. NN based Generalized Softmax Percepron (GSP) and supervised learning algorithms were used to predict different development stages. Result was obtained in terms of multiple classes or stages using Posterior Probability Model Selection (PPMS) algorithm. Later, authors were able to determine landmarks of radius, ulna and short bones - phalanxes and metacarpals automatically and successfully. But authors were not able to integrate them because of high precision marking in phalanxes and metacarpals borders and low precision marking in radius and ulna edges. In 2009, Thodberg HH [71] presented BoneXpert method - a new bone age scheme on different rules than TW and G\&P method that reconstructs borders of 13 RUS bones automatically to compute bone age. The proposed system used 1559 images of hand-wrist in age range of 2-17 years. Active appearance Model (AAM) which were trained on 3000 manually localized bones and PCA made a robust algorithm to derive shape, intensity and texture scores from bone reconstruction for BoneXpert system. Clinically the proposed system proved $99 \%$ validation with obtained results. In 2011, Tise [72] had applied GP method to assess skeletal maturity for criminal liability and identifying age of minor migrants. In Italian law, Person above 14 years was considered as criminally responsible and at the age of 18 years as an adult and legally important. Authors identified that G\&P method was reproducible and repeatable because of wide margin of error in identifying maturity and age critically ages of 14 and 18. Authors concluded that the method could be used for clinical purpose but second opinion required in case of legal purposes. For second opinion studies are required to consider combined analysis of physiological and biological parameters to reduce the error.

In 2011, Krit Somkantha [73] proposed a technique for assessment of skeletal maturity for young children aged between 0-6 years old. Five features such as number of carpal bones (F1), ratio between total of all carpal bone area and total capitate area (F2), ration between total of all carpal bone area and hamate area (F3), ratio between perimeter of capitate and calculating root of sum of squares of centroid coordinates of capitate and hamate (F4) and ratio between total of all carpal bone area and calculating sum of squares of centroid coordinates of capitate and hamate (F5) are used in feature extraction. Author evaluated the performance of system for Support Vector Regression (SVR) and three layer back-propagation NN with one hidden layer with two neurons. 180 X-ray images are processed. Author concluded from results that SVR was more accurate than NN. In 2012, Mansorvar proposed Histogram based a novel approach to determine the skeletal maturity on radiographic images of hand-wrist bone area. The system provides age estimation of hand-wrist X-rays upto the age of 18 years. The system utilized Content Based Image Retrieval (CBIR) to compare the images based on query related to generate histogram. The system was compared with BoneXpert system and resulted in -0.17 years error rate. In 2012, J. Seok [74] proposed fully automated G\&P atlas system using machine learning approach. Author used image morphing technique to create modified G\&P system. Image morphing was followed by feature extraction where edges, texture, color features were extracted by Scale Invariant Feature Transform (SIFT) method and then feature vector was generated by Sigular Value Decomposition (SVD). Last step involved NN to train and classify the feature vectors. Authors used only 24 images in the range from 6 years to 11 year 9 months dataset in whole process. Due to insufficient training data large error was obtained between standard G\&P number and 
authors' modified G\&P number. In 2014, Mansorvar [75] proposed combined method of hand-wrist and clavicle. The research used a questionnaire on quantitative and qualitative methods to collect the data to understand the main issues concerning BAA and mentioned that manual methods are time consuming and observations are subjective. Author used BAA1 subsystem for hand-wrist images and BAA2 subsystem for clavicle images. The integrated system did decision making by comparing images with the image repository and the results are obtained. In 2015, Urschler et al.[76] evaluated MRI based skeletal maturation using landmark localisation algorithm and Regression Random Forest (RRF) decision tree algorithm. Author examined anatomical changes only in male adolescents aged between 13-20 years. Among 24 bones, radius and ulna bones had given very nearby results than carpals and metacarpals. The selected age group might be the problem for inaccuracy in estimation as during 14-16 years children enters in puberty stage, so more biological variations occur. Overall authors found 0.85 years of mean absolute difference in automated method compared with manual methods chronologically and concluded that RRF was well suited to non-linear regression of MRI features to chronological age. Authors also mentioned future scope using MRI scans that not only bone structure but also soft tissues like cartilage and bone marrow can be used further.

So it will be good idea to extend proposed method using its features. In 2016, Ji. Zhang [77] performed analysis based on automatic BoneXpert method and Manual G\&P method for skeletal maturity of hand-wrist bones of Chinese sample of 229 boys and 268 girls aged between 2-14 years. Proximal, middle and distal phalanges, metacarpals and distal ends of radius and ulna ROI was assessed based on both methods mentioned above and bone age was calculated. Authors performed statistical analysis of bone age vales and concluded that distal phalanges are more useful and reliable for bone age estimation. Distal radius and ulna and distal phalanges failed because of overlapped bone regions. Even though MRI was radiation free but it requires more acquisition time which gives additional stress to the patient under observation. To overcome this drawback Neumayer et al. in 2017 [78] investigated reduction in acquisition time method that leads to appropriate age estimation. Author used "Controlled aliasing in parallel imaging results in higher acceleration" method on under-sampled data to optimize acceleration of 3D images. Then total generalized variation (TGV) regularization strategy was applied to reconstruct the simulated images. The proposed method was applied to hand-wrist MRI of both original and simulated images for age estimation task which then further compares manual and automated evaluation. Manually, examination was performed by radiologists using G\&P method and automatically by Urschler et al. method.

\section{b. Femur-Tibia Examination:}

Table 10. Survey of femur-Tibia based techniques [79-85]

\begin{tabular}{|c|c|c|}
\hline Authors/year & Method \& Bone used & Result Analysis \\
\hline Kerley (1965) & $\begin{array}{l}\text { Manual method: } \\
\text { Regression Analysis/ } \\
\text { Tibia, Fibia and Femur } \\
\text { bones }\end{array}$ & $\begin{array}{l}\text { Age-at-Death transverse ground cross-section taken } \\
\text { from the mid shaft of bone samples : } \\
+/-9.1\end{array}$ \\
\hline $\begin{array}{l}\text { Ahlqvist and Damsten } \\
(1969) \quad \text { (modified } \\
\text { kerley) }\end{array}$ & $\begin{array}{l}\text { Manual method/ Only } \\
\text { Femur/ Femur and Tibia }\end{array}$ & $\begin{array}{l}\text { Revised (Kerley's) the technique to measure histological } \\
\text { structure within a square field to avoid the difficulty in } \\
\text { distinguishing histological structures in the proximity of the } \\
\text { circular field limits. } \\
+/-6.71\end{array}$ \\
\hline $\begin{array}{ll}\text { Singh } & \text { and } \\
\text { Gunberg(1970) } & \end{array}$ & $\begin{array}{l}\text { Manual method/ Femur } \\
\text { and Tibia }\end{array}$ & $\begin{array}{l}1 \mathrm{~cm} \times 1 \mathrm{~cm} \text { fragments of anterior and posterior border } \\
\text { from the midshaft of femurs and tibia }+/-5.01\end{array}$ \\
\hline Thompson (1979) & $\begin{array}{l}\text { Manual method/ Femur } \\
\text { and Tibia }\end{array}$ & $\begin{array}{l}\text { Anterior portion of femurs and tibia, humeri and ulnae } \\
\text { and recorded nineteen variables } \\
\text { +/-12.94 RTibia } \\
\text { +/- 13.56 LFemur } \\
\text { +/- 13.33 LTibia } \\
\text { +/-12.76 R Femur }\end{array}$ \\
\hline Ericksen $(1980,1991)$ & Manual method/ Femur & $\begin{array}{l}+/-10.07(1980) \\
+/-12.21(1991)\end{array}$ \\
\hline $\begin{array}{llll}\text { Faridah Nor et al. } \\
(2016)\end{array}$ & $\begin{array}{l}\text { Manual method/ tibia, } \\
\text { femur, radius, ulna, } \\
\text { fibula, and humerus }\end{array}$ & +/- 10.94 years \\
\hline $\begin{array}{l}\text { Vidyashree H S and } \\
\text { Pradeep N (2017) }\end{array}$ & $\begin{array}{l}\text { Manual method and } \\
\text { automated method with } \\
\text { ANN /Femure }\end{array}$ & Age at death \\
\hline
\end{tabular}


Femur was the longest and strongest bone in the human skeleton and it was normally preserved for forensic contexts. Very few and manual methods were used for femur-tibia examination. In 1965, E. R. Kerley [79] observed 126 specimens of age range from birth to 95 years using femur, tibia fibula such long bones. Author examine microscopic changes counting four features: Number of Osteaons number (F1), Number of fragments of old osteaons (F2), The percentage of circumferential lamellar bone (F3) and number of non-Harvesian canal s (F4) in mid-shaft of each leg bone for incomplete bones or by taking cross section (Fragmented bone) at the midshaft of each complete bone. The nearby accuracy with error rate of \pm 5 years was obtained in osteaon fragment number in fibula. Author faced a problem in identifying "recognisable osteaon" and "fragments" that are detected beyond borders by subsequent generations of osteaons. In 1970, I. J. Signh and D. L. Gunberg [80] concentrated on measuring skeletal maturity for older human population in contrast to previous method those had used age estimation methods for below 25 years. Authors measured 3 features from cross sections of mandible, femur, tibia in 52 males and 7 females ranging age between 39 to 87 years. Author applied multiple regression analysis on obtained feature vector to relate histological age changes in human. It was concluded that quantitative measures of microstructure of bone cortex are important in estimating age at death and found that closure of Harvesian canal continues in $80 \mathrm{~s}$. Author faced challenges in variability of measurement system where an individual may undergone through major surgery or effects of illness nutrition or any other personal history like having permanent disease like diabetes. Robert walker and C. Owen Loverjoy in 1985 [81] examined radiographic changes in clavicle, humerus and femur bone to determine skeletal maturity (age) at death. Radiographic changes found are compared with anatomical changes of every bone as per summary age table 2 and it was concluded that lateral clavicle and proximal humerus radiographs are more useful and could provide additional information over 40 years of age in determining age at death in females.

According to author, as an age indicator in male proximal femur was more superior to clavicle and humerus with minimum bias. Till 2005, authors used X-ray radiographs for skeletal maturity determination. In 2005, first time in forensic science applications new technology called Dual energy X-ray Absorptiometry (DXA) had been used by Wheatley. Author calculated bone mineral density (BMD) and bone mineral content (BMC) to evaluate sex and body ratio from proximal femur bone. These measures are useful in cause-effect relationship between bone mineralization and skeletal loads. Many papers reported in literature are based on anterior cortex of femur in microscopic examination to determine skeletal maturity, age and gender of a person. S. Han (2009) et al. developed an equation for age prediction based on microscopic examination of anterior cortex of femur. $1 \mathrm{~mm}$ thick cross-sections of mid-shaft was obtained from right femur of specimens. Four morphological parameters most anterior cortical width (CW), Osteaon Population Density (OSD), Average size of osteaon (OA) and Harvesian canal (HA) measurements over five different areas were taken on protractor.

After 4 years gap, In 2016, Nor [83] FM performed same microstructure analysis and counted microstructural parameters from cross sections of long limb bones in Malaysian males. (Histological parameters, namely osteaon count (OC), osteaon diameter (OD), Harvesian canal diameter (HCD), osteaon area (OA), Harvesian canal area (HCA), osteaon perimeter (OP), Harvesian canal perimeter (HCP), and Harvesian lamellae count (HLC) were measured). Multivariate regression analysis was performed on these microscopic parameters and then lowest Standard Error Estimate (SEE) value equation was selected for cross validation. Among osteaon parameters, OC showed significant correlation with age. Correlation coefficient R was 0.61 and SEE was 9.71 which were minimum among literature studied in this paper. Vidhyashree H. S. in 2017 [85] explained various features of teeth, femur and hand-wrist bone used for age and gender identification. After a long time, David Navega et al. in 2017 proposed a new method based on DXA femur bone. Many researchers used regression analysis on calculated measurements but very few have used ANN for femur bone assessment. David used ANN to model data obtained from DXA. BMD feature was used to obtain the age at death in human remains. Dataset 100 femora of only female collected from Coimbora Identified Skeletal Collection. BMD total, BMD ward and BMD neck data were counted twofold-one by scanning DXA repeatedly and second by taking precise measurements by densitometer to evaluate intraobserver error.

\section{c. Clavicle Examination:}

Table11. Survey of clavicle based techniques [86-95]

\begin{tabular}{|l|l|l|}
\hline $\begin{array}{l}\text { Authors/year } \\
\text { Kreitner et al.. (1997, } \\
\text { 1998) }\end{array}$ & Manual method/Clavicle CT scan & Result Analysis \\
\hline $\begin{array}{l}\text { Schmidt et al. (2004, } \\
\text { 2007) }\end{array}$ & $\begin{array}{l}\text { Manual method/ MRI of 54 sterno } \\
\text { clavicular joints }\end{array}$ & $\begin{array}{l}\text { Required 3 hours time to estimate hence in living } \\
\text { persons not suitable }\end{array}$ \\
\hline Schulz et al. (2005) & Manual method/ CT scan - Slice & Arises question in paper that if slice thickness \\
\hline
\end{tabular}




\begin{tabular}{|c|c|c|}
\hline & thickness of $>1 \mathrm{~mm}$ & $>1 \mathrm{~mm}$ interpretation could vary \\
\hline Muhler et al. (2006) & $\begin{array}{l}\text { Semi-automated method/ CT- } \\
\text { Scans with layer thickness of } \\
1,3,5,7 \mathrm{~mm}\end{array}$ & $\begin{array}{l}\text { Shows different diagnosis on different slice } \\
\text { thickness..concluded that } 1 \mathrm{~mm} \text { was more accurate } \\
\text { and reliable. }\end{array}$ \\
\hline $\begin{array}{l}\text { Kellinghaus et al. } \\
\text { (2010a) }\end{array}$ & $\begin{array}{l}\text { Automated method/ Thin slice of } \\
\text { CT scan }\end{array}$ & Found results same as Schmeling et al. 2004 \\
\hline Hillewig et al. (2013) & $\begin{array}{l}\text { Baysian Statistic Model/ Thin } \\
\text { slice of CT scan }\end{array}$ & Suggested additional handwrist examination \\
\hline $\begin{array}{l}\text { Wittschieber et al. } \\
(2013) \text {. }\end{array}$ & Automated method & Above legal age reached 19 confirmed. \\
\hline $\begin{array}{l}\text { Inthasan C and } \\
\text { Mahakkanukrauh P. } \\
\text { (2017) }\end{array}$ & Manual Method & Intra-Observer Error \\
\hline
\end{tabular}

Clavicle was non-weight bearing bone and usually found as entire bone. Age estimation using Clavicle bone mostly performed on Caucasian population. In 1998, K. F. Kreitner [86] had used Computed Tomography (CT) to determine epiphyseal maturation of clavicle bone in addition with X-ray examinations of hand and pelvis to assess age of an individual in forensic use. Cases with different thickness $8 \mathrm{~mm}, 5 \mathrm{~mm}, 4 \mathrm{~mm}, 3 \mathrm{~mm}, 2 \mathrm{~mm}$ and $1 \mathrm{~mm}$ of joint regions of clavicle were assessed according to four stages of maturation of clavicle epiphysis. Author found similar development pattern in left and right clavicle epiphysis between males and females and overall at every stage approximate 10 years of age range was identified. In 2003, A. Schmeling [87] studied traditional four stage clavicle ossification and added stage 5 for more accuracy.

The earliest age was 16 years at stage 3 was observed in both sex. Stage 4 was first detected in females at 20 years and in males at 21 years. Stage 5 was first by both genders at age 26 years. It was concluded that plain chest radiographs could provide a basis for examining clavicular ossification. If posterior-anterior views overlapped and affects evaluation, then additional lateral images should be considered to facilitate age estimation. Later in $2005 \mathrm{Schulz}$ et al.[88] raised a question that whether slice thickness affects in estimating age groups and presented that at stage 5 which was defined by schmeling high thickness of slices on CT scans and its statistical measurement data could not be used for forensic purpose. Instead, author recommended $1 \mathrm{~mm}$ slice thickness for maximum accuracy and best possible results. Similarly Muhler et al. [89] added confirmation on using $1 \mathrm{~mm}$ slices of CT scan to evaluate the development of epiphysis and clavicular ossification for forensic purposes. It should be very cautious while applying in criminal cases where the person under examination would have been assessed higher than age the actual age.

The concerned person may be considered as an accused criminal and lead to major punishment. In 2006, first time S. Schimit et al. [90] analyzed skeletal maturity of medial clavicular joints using MR Scans. Even though MR scans are taken without radiation exposure, to date, they were rarely used in skeletal development. Most of the time radiography was not allowed in civil and asylum proceedings due to harmful radiations which results in single option that was only physical examination. This leads to increase in estimation error and more chances to declare the person under examination as an accused/criminal. Author considered these as challenges and performed assessment using MR scans. Improving result showed age identification in stage 2 at the age of 15.0 years which was not estimated earlier in [86]. In this study, MR scans required much more time in measuring data than that of previous methods (image acquisition was faster in CT scan than MR Scan).

Author mentioned future scope in reducing image processing time in MR scans. In 2010, M. Kelinghaus et al. [91] assessed 185 patients age from 13 years to 26 years. Author subdivided stage 2 and 3 into early(a), intermediate(b) and later(c) stages each of sternal extremity of the clavicle to estimate more accurate results. Stage 3 appeared at 19 years of age so that it was possible to substantiate an individual has already reached the legally important age threshold of 18 year in India even if epiphyseal and metaphyseal fusion was not completed. In 2013, considering future scope of Kelinghaus, A. Hillewig [92] (220 volunteers from 16-26 age groups) used Bayesian statistics model had been used to evaluate and validate different development stages of sternal extremity of the clavicle. Authors found challenges in assessment of stage from I to IV in some MRI cases. In such cases author suggested additional hand-wrist examination. In the same year, Schulz et al. [88] examined medial clavicular epiphysis using sonography in 309 male and 307 female healthy volunteers aged between 10 and 25 years. The mean for stage 1 showed 13.6 years. The means of stage 2 varied a range between 17.3 and 17.6 years. For stage 3 the means were from 20.7 to 21.2 years, and for stage 4 they showed between 23.3 and 23.5 years. Schulz raised the question of ethical impact on ossification of bone but in [87], it was concluded that ethnical origin does not influence the ossification rate but the low socio-economic status of an individual may delay the skeletal development. Similarly, D. Wittschieber [94] along with Schulz, examined 0.6mm thin slice of 
CT -scan of sterno-clavicular joints of 572 individuals between 10 to 40 years of age. Wittschieber used larger image dataset with larger age group and very thin-slice of CT-scan than all previous studies. Authors used clavicular sub stages of Kellinghaus et al. to assess the sterno-clavicular joints. Results showed 1 year earlier in every stage than other studies. Comparing with X-rays and Sonographic studies Ct-scan gives higher quality images which improved the results [91].

\section{Opportunities and Challenges}

\subsection{Aging Features}

Human development stages and age markers may be inconsistent and variable as observed in physical appearance or behavior pattern. It also depends on the gender of a person. The female age may have different age markers than the male age. Fingerprints, iris examinations in children are exceptionally difficult to match as it would be falsely rejected by the systems. Many papers, primarily based on fingerprint, iris, whole blood, face, voice, etc., are used to identify a specific age group. In every section above, respective aging feature has discussed challenges that were faced in the process. Some general challenges that are observed in most of aging features are abnormalities in body parts, missing body part. Inconsistency in estimation may be problematic for age 16,17, 18 and 21. Age estimation of asylum seekers particularly faces the challenges like their psychological background in unfortunate circumstances during war or poverty. Humans that are from variable in race, gait due to environmental factors such as cold, nutritional intake also affects to age estimation. Variety, obesity, morphological changes in working population can be the causes. Socio-economic variation for bone development due to nocturnal enuresis, growth hormone, competitive sports, skeletal malformation, deficiency in vitamin D and Calcium levels.

\subsection{Automated Approaches}

In automated method, the first process is of object localization or recognisation. A medical image consists of information with respect to anatomical context. This anatomical context is categorized into three types, namely local context, higher order context and global context. Exhaustive scanning of the image is needed to localize the object in local context. It can be performed using learned classifier. Distance measure is needed for pair wise or high order context and a regression function can be used to learn and predict the object location directly from any pixel. Learning a binary classifier is easier than a regression, however exhaustive scanning is more computationally intensive than testing few locations. Object detection methods based on classification based aims to separate the object as foreground from background using discriminative classifiers. Boosting detection method uses 2D face by exhaustively searching. There are three contributions, Adaboost algorithm for feature selection that uses an integer image for faster evaluation of features and training a boosting cascade to quickly eliminate negatives. The drawback of this method is in rejecting more negatives; each classifier also loses a few positives. Probabilistic boosting tree is binary decision tree with boosting.

Letting each tree node be an adaboost classifier. This way gives chance of correct classification of examples. Another most widely used method is Randomized Decision Forest that automatically detects and localizes anatomical structure. The Exhaustive search method handles pose variations. Probabilistic boosting network is a Multiclass LogitBoost algorithm. Marginal Space Learning mostly focuses on structures for efficient detection. Multiple Instance Boosting use to handle inaccurate annotation: Multiple Instance Learning uses instance bags as inputs for training. Positive bag to guarantee that true positives inside it. Multiple Instance Boosting combines Multiple Instance Learning with cost function and achieved improved performance in object detection. Mostly used in the literature regression based methods are shape regression machine and Hough forest. After the object is detected, the next process is to perform precise image segmentation again using local context between shape and appearance bounding box. Each segmentation region composed of set of pixels or voxels. Simple image segmentation method is thresholding. In thresholding, the key is to utilize proper threshold value. Michel and Nelson-1989 [58], Pietka-1991 [66] used semi-automated process based on thresholding.

Histogram equalization and thresholding was implemented in preprocessing the radiographic images acquiring the histogram peak of pixels intensity followed by eliminating background. Drawback of this method was the overlapping problem of pixel intensity in bone and background. High intensity of pixels illuminates uniformity and presence of soft tissue region degenerated the results obtained. Clustering with K-means, Region growing methods by calculating the image feature values with a proper feature choice, segmentation becomes more robust. Active contour method is widely uses gradient vector flow that minimizes the cost function. Drawback of this method that it is counter sensitive to intensity gradient depends heavily on initial position and exhibits inability in extending into concavity [58]. Active Shape Model and Active Appearance Model also 
called as deformable models are most popular methods in segmentation. Active shape model uses point based representation and then generated model is learned with Principal Component Analysis. Line by line search is used to fit the model. In Active appearance model, appearance issued in addition to shape to generate linear model. Analysis by synthesis approach is used to fit the model in Active appearance model. These models were used by Sasaan Mehmoodi, 2000 [65], Thodberg - BoneXpert method 2009 [71] in the literature.

A local context segmentation approach based on active shape models proved to be a robust alternative in these studies in order to estimate the skeletal growth. The main drawback of Active Shape Model is associated with the sensitivity in uneven illumination and presence of soft tissue region and that is not yet developed into fully automated system as landmarks placement is still annotated manually. With respect to Active Shape Model, Active Appearance Model increases robustness of model. Graph cut method is the hybrid method of classification and regression. Image grid points and neighbouring pixels are connected with edges as similar to Markov Random field. Deep learning methods: Logistic regression is binary classification problem uses sigmoid function also called as squashing function. Neural Network:-Multiple choice decisions can be made. It is extended form of Logistic regression [70]. Backpropogation is mostly popular method in Neural Networks that efficiently compute gradient of cost function, [58],[65] for the first time had used in computing skeletal age with respect to G\&P method which was involved only visual observation.

Author [73] segmented the carpals bone using the combination of vector image model and canny edge detection. Fuzzy classification was used by Chi-Wen Hsieh [68] in 2006. Urschler et al. 2015 [76], evaluated MRI based skeletal maturation using landmark localization algorithm and Regression Random Forest (RRF) decision tree algorithm and concluded that RRF was well suited to non-linear regression of MRI features to chronological age. Papers that are mainly based on dental and skeletal developments are manual and semiautomated approaches for human age estimation. Very few papers have proposed fully automated approaches. Histological, Clinical, or visual observations; the manual methods are time-consuming, faces intra and inter observer inconsistencies, and require equipment for good results. In case of automated methods, pre-processing stage removes background and rejects the low quality images. Image capturing modalities like X-ray, CT-scan, MRI provides three dimensional views with thin slices, but the problem still resist for small set of bones such as carpals. A major limitation is the unavailability of labeled data, dataset of particular modality on particular bone, privacy and legal issues, dedicated medical experts. Noisy mages, incomplete data or poor contrast of some sections makes feature extraction very difficult from an image, ROI extraction is the main challenge. Image Segmentation separates specific region but small region depends on attributes in X-ray intensity or bone texture.

\section{Conclusion}

This paper presented a new dimension to age estimation. Automated methods are more feasible than manual and semi-automated methods as it helps in reducing the human observation error and computation time, and the use of clinical equipments. Now it is time to focus on structurally and biologically inspired different features and models such as analysis of skeleton bones with neural networks. Promising results have been reported on physiological, biological features and combination of the features on neural network methods. Although today's systems have more potential to automate the processes using different algorithms, there are also some important challenges. A major limitation for biological features is the unavailability of labeled data, privacy and legal issues, dedicated medical experts, and non-standard machine learning algorithms for different medical image modalities such as X-ray, MRI, CT-scan. Fully automated method using multi-feature descriptors is recommended for high accuracy in human age estimation.

\section{References}

1. Wilton Marion Krogman, "The human skeleton in forensic medicine”, Charles C Thomas Publisher, U. S. A. (1962)

2. Line Eikvil, Sirgid Ingeborg Kvaal, Andre Teigland, Marion Haugen, Jens Grogaad, "Age Estimation in youth and young adults", Norwegian Computing Center, December 2012, SAMBA/52/12.

3. Rita Singh, Joseph Keshet, Deniz Gencaga, Bhiksha Raj, "The Relationship of Voice Onset Time And Voice Offset Time To Physical Age” 2016 IEEE, ICASSP 2016, 978-1-4799-9988-0/16, pp. 5390-5394.

4. Charl van Heerden, Etienne Barnard, Marelie Davel, Christiaan van der Walt Ewald van Dyk, Michael Feld, Christian M. Uller, "Combining Regression And Classification Methods For Improving Automatic Speaker Age Recognition” 2010, IEEE ICASSP 2010,978-1-4244-42966/10, pp. $5174-5177$. 
5. N. Minematsu, M. Sekiguchi, and K. Hirose, “Automatic Estimation of One's Age with His/Her Speech Based upon Acoustic Modeling Techniques of Speakers”, In Proc. IEEE Int. Conf. Acoust., Speech, Signal Process., pp. I-137-I-140, 2002.

6. C. Muller, F. Witting, and J.Baus, "Exploiting Speech for Recognizing Elderly Users to Respond to Their Special Needs”, In Proc. Eur. Conf. Speech Communication and Technology, 2003.

7. C.I. Tomai, D.M. Kshirsagar, and S.N. Srihari, "Group Discriminatory Power of Handwritten Characters", In: Electronic Imaging, pp. 116-123, International Society for Optics and Photonics, 2003.

8. K. Bandi and S.N. Srihari, “Writer Demographic Classification Using Bagging and Boosting”, In Proc. Int. Graphonomics Society Conference, pp. 133-137, 2005.

9. Marcus Liwicki, Andreas Schlapbach, Peter Loretan, "Automatic Detection of Gender and Handedness from On-Line Handwriting”, eBeam System by Luidia, 2007.

10. Shubhangi D.C., Dr. P.S.Hiremath, "Determination Of Writer's Age Using English Handwritten Documents”, International Journal Of Computer Science And Applications Vol. 3, No. 1, January / February 2010, pp 1-6.

11. Somaya Al Maadeed and Abdelaali Hassaine, Al Maadeed and Hassaine "Automatic prediction of age, gender, and nationality in offline handwriting”, EURASIP Journal on Image and Video Processing, Springer.

12. Nesrine Bouadjenek, Hassiba Nemmour and Youcef Chibani, "Age, Gender and Handedness Prediction from Handwriting using Gradient Features”, IEEE 2015 13th International Conference on Document Analysis and Recognition (ICDAR), pp: 1116-1120.

13. J.W. Davis, "Visual Categorization of Children and Adult Walking Styles", In Audio-and VideoBased Biometric Person Authentication, pp. 295-300, 2001.

14. R.K. Begg, M. Palaniswami, and B. Owen, "Support Vector Machines for Automated Gait Classification”, IEEE Trans. Biomed. Eng., vol. 52, no. 5, pp. 828-838, 2005.

15. Ju Han, Bir Bhanu, "Individual Recognition Using Gait Energy Image", IEEE Transactions on Pattern Analysis and Machine Intelligence, March 2006, pp 316-322.

16. Y. Makihara, H. Mannami, and Y. Yagi, "Gait Analysis of Gender and Age Using a Large-Scale Multi-View Gait Database”, In Proc. Asian Conf. Comput. Vis., pp. 440-451, 2010.

17. J. Lu and Y.P. Yan, "Gait-Based Human Age Estimation”, IEEE Trans. Inf. Forensics Security, vol. 5, no. 4, pp. 761-770, 2010.

18. Y. Makihara, H. Mannami, and Y. Yagi, "Gait Analysis of Gender and Age Using a Whole generation Gait Database”, IEEE 2011.

19. Jiwen Lu, Gang Wang, and Pierre Moulin, "Human Identity and Gender Recognition from Gait Sequences with Arbitrary Walking Directions" IEEE Transactions on Information Forensics and Security, Vol. 9, NO. 1, JANUARY 2014, pp 51-60.

20. X. Geng, Z.-H. Zhou and K. Smith-Miles., "Automatic age estimation based on facial aging pattern”, IEEE Transactions on Pattern Analysis and Machine Intelligence, vol. 29, pp. 22342240, 2007.

21. K. Luu, K. Ricanek Jr, T. D. Bui and C. Y. Suen., "Age estimation using active appearance models and support vector machine regression," IEEE 3rd International Conference on Biometrics: Theory, Applications, and Systems (BTAS), pp. 1-5, 2009.

22. Y. Fu, G. Guo and T. S. Huang., "Age synthesis and estimation via faces: A survey," IEEE Transaction on Pattern Analysis and Machine, vol. 32, pp. 1955-1976, 2010.

23. X. Geng, Z.-H. Zhou, Y. Zhang,G. Li and H. Dai., "Learning from facial aging patterns for automatic age estimation," Proceedings of the $14^{\text {th }}$ annual ACM international conference on Multimedia, pp.307-316, 2006.

24. A. Gunay and V. V. Nabiyev., "Automatic age classification with LBP," 23rd International Symposium on Computer and Information Sciences(ISCIS), pp. 1-4, 2008.

25. F. Gao and H. Ai., "Face age classification on consumer images with gabor feature and fuzzy lda method," Springer Advances in biometrics, pp. 132-141, 2009.

26. H. Han, C. Otto, X. Liu, and A. Jain, "Demographic Estimation from Face Images: Human vs. Machine Performance”, IEEE Trans. Pattern Anal. Mach. Intell., vol. 37, no. 6, pp. 1148-1161, 2015.

27. Y.H. Kwon and N.D.V. Lobo, “Age Classification from Facial Images”, In Proc. IEEE Int. Conf. Computer Vision Pattern Recognition, pp. 762-767, 1994.

28. G. Guo, G. Mu, Y. Fu, and T.S. Huang, "Human Age Estimation Using Bio-Inspired Features”, In Proc. IEEE Int. Conf. Computer Vision Pattern Recognition, pp. 112-119, 2009.

29. Dileep M R and Ajit Danti, "Multiple Hierarchical Decision on Neural Network to predict Human Age and Gender”, IEEE 2016. 
30. Vojtech Franc and Jan Cech, "Learning CNNs for face recognition from weakly annotated images”, 2017 IEEE 12th International Conference on Automatic Face \& Gesture Recognition, pp. $933-940$.

31. Edward E. Hunt, Jr. Izaac Gleiser, "The Estimation of Age and Sex of Preadolescent Children from Boxes and Teeth", Age and Sex of Children, pp. 479-487.

32. Kaarina Haavikko, "Tooth Formation Age Estimated on a Few Selected Teeth: A Simple Method for Clinical Use”, Proc. Finn. Dent. soc. 70: 15-19, 19/4.

33. A. Demirjian and H. Goldstein, "New systems for dental maturity based on seven and four teeth", Annals of Human Biology, 1976, Vol. 3, No. 5, 411-421.

34. Harris, E. F. and McKee, J. H., "Tooth Mineralization Standards for Blacks and Whites from the Middle Southern United States," Journal of Forensic Sciences, JFSCA, Vol. 35, No. 4, July 1990, pp. 859-872.

35. Sigrid I. Kvaal, Kristin M. Kolltveit, Ib O. Thomsenb, Tore Solheima, "Age estimation of adults from dental radiographs" Forensic Science International, 1995, pp. 175-185.

36. Roberto Cameriere, Luigi Ferrante, and Mariano Cingolani, "Variations in Pulp/Tooth Area Ratio as an Indicator of Age: a Preliminary Study”, J Forensic Sci, Mar. 2004, Vol. 49, No. 2, pp. 1-3.

37. R. Cameriere et al. "Age Estimation by Pulp/ Tooth Ratio in Canines by Mesial and Vestibular Peri-Apical X-Rays", Forensic Sci, September 2007, Vol. 52, No. 5 pp. 1151-1155, doi: 10.1111/j.1556-4029.2007.00530.x.

38. Hala Mohamed Ahmed, Ashraf Abd Alazim Ewiss, Nagwa Mohamed Khattab, and Maha Eshak Amer, "Age Estimation through Dental Measurements Using Cone-Beam Computerized Tomography Images in a Sample of Upper Egyptian Population”, Ain Shams Journal of Forensic Medicine and Clinical Toxicology, July 2013, 21:pp. 75-88.

39. R. Cameriere et al. "Automatic age estimation in adults by analysis of canine pulp/tooth ratio: Preliminary results”, Journal of Forensic Radiology and Imaging, 3 (2015),pp. 61-66.

40. Aka P. Sema, Yagan Murat, Canturk Nergis and Dagalp Rukiye, "Direct and Indirect Forensic Age Estimation Methods for Deciduous Teeth”, 2015, Forensic Research, http://dx.doi.org/10.4172/2157-7145.1000273.

41. Nagi R et al., "Tooth coronal index: Key for age estimation on digital panoramic radiographs", J. Indian Acad Oral Med Radiol 2018; 30:64-7, DOI: 10.4103/jiaomr.jiaomr_139_17.

42. Gerda J. Edelman, Martin Roos, Annabel Bolck, Maurice C. Aalders, "Practical Implementation of Blood Stain Age Estimation Using Spectroscopy”, IEEE Journal of Selected Topics in Quantum Electronics 2016.

43. Ferdi Sarac, Huseyin Seker, Ahmed Bouridane, "Exploration of Unsupervised Feature Selection Methods to Predictive Chronological Age of Individuals by Utilising CpG dinucleotics from Whole Blood", IEEE 2017, pp. 3652-3655.

44. Ceyhan, Sagiroglu,Tatoglu, Atagun, "Age Estimation from Fingerprints: Examination of the Population in Turkey", 13th International Conference on Machine Learning and Applications, 2014, IEEE Computer Society, pp. 478-481, DOI 10.1109/ICMLA.2014.83.

45. Ceyhan, Sagiroglu, Cesur, K. Oner, "Automatic Gender Classification System From Finger 2D:4D Ratio and Comparison of Successes with Using Different Algorithm”, 13th International Conference on Machine Learning and Applications, 2014, IEEE Computer Society, pp. 600-606, DOI 10.1109/ICMLA.2014.103.

46. Basavaraj Patil G.V, Mohamed Rafi, "Human Age Estimation through Fingerprint”, International Journal of Innovative Research in Computer and Communication Engineering Vol. 3, Issue 4, April 2015 , pp. 3530 - 35305, DOI: 10.15680/ijircce.2015.0304125.

47. Aditya K. Saxena, Shweta Sharma and Vijay K. Chaurasiya, "Neural Network based Human Agegroup Estimation in Curvelet Domain”, Elsevier, ScienceDirect, Eleventh International MultiConference on Information Processing-2015 (IMCIP-2015), pp. 781-789.

48. Prabha, Jitendra Sheetlani, Rajmohan Pardeshi, "Fingerprint based Automatic Human Gender Identification”, International Journal of Computer Applications (0975 - 8887) Volume 170 - No.7, July 2017.

49. Xianchao Qiu, Zhenan Sun, and Tieniu Tan, "Learning Appearance Primitives of Iris Images for Ethnic Classification”, IEEE ICIP 2007.

50. Stephen Lagree and Kevin W. Bowyer, "Predicting Ethnicity and Gender from Iris Texture".

51. Atul Bansal, Ravinder Agarwal, R.K. Sharma, "SVM Based Gender Classification Using Iris Images”, IEEE Computer Society, 2012, pp. 425-429, DOI 10.1109/CICN.2012.192.

52. Juan Tapia Farias, Claudio Perez, "Gender Classification from Iris Images using Fusion of Uniform Local Binary Patterns”, September 2014, DOI: 10.1007/978-3-319-16181-5. 
53. Thomas M. Carter, "Technique and Devices Used in Radiographic Study of the Wrist Bones of Children”, The Journal of Educational Psychology, 1926.

54. Garside, Helen, V., "Anatomic growth of children A study of some bones of the hand, wrist, and lower forearm by means of Roentgenograms”, Univ Iowa Studies Child Welfare, 1928,pp. 1-88.

55. Greulich, W. W. and Pyle, S. I., "Radiographic atlas of skeletal development of the hand and wrist", The American Journal of the Medical Sciences, 1959, 238(3):393.

56. Tanner J. M., Whitehouse R., Marshall W., Healty M., and Goldstein H., “Assessment of skeleton maturity and maturity and prediction of adult height", 1975a.

57. Tanner J. M., Whitehouse R., Marshall W. A., and Carter, B. S., "Prediction of adult height from height, bone age, and occurrence of menarche, at ages 4 to 16 with allowance for midparent height", Archives of Disease in Childhood, (1975b). 50(1), pp. 14-26.

58. WM. Cameron Chumlea, Alex F. Roche, and David Thissen, "The FELS Method of Assessing the Skeletal Maturity of the Hand-Wrist”, American Journal Of Human Biology, 1989,pp. 175-183.

59. David J. Michael and Alan C. Nelson, "HANDX: A Model-Based System for Automatic Segmentation of Bones from Digital Hand Radiographs", IEEE Transactions on Medical Imaging. VOL 8, No. 1, March 1989, pp. 64-69.

60. Ewa Pietka, Michael F. McNitt Gray, M. L. Kuo, and H. K. Huang, "Computer- Assisted Phalangeal Analysis in Skeletal Age Assessment”, IEEE Transactions On Medical Imaging, Vol. 10. No. 4, December 1991, pp. 616-620.

61. K Hill and PB Pynsent, "A fully automated bone-ageing system”, Acta Psdiatr Suppl 406,1994, pp.81-83.

62. George W. Gross, John M. Boone, Dorene M. Bishop, BS, “Pediatric Skeletal Age: Determination with Neural Networks”, Radiology 1995, Vol. 195, pp. 689-695.

63. M. Rucci, G. Coppini, I. Nicoletti, D. Cheli, and G. Valli, "Automatic Analysis of Hand Radiographs for the Assessment of Skeletal Age: A Subsymbolic Approach”, Computers and Biomedical Research, Vol 28, 1995, pp. 239-256.

64. Sato et al., "Setting Up an Automated System for Evaluation of Bone Age", Endocrine Journal 1999, 46 (Suppl), S97-S100.

65. Sasan Mahmoodi, Member, Bayan S. Sharif, E. Graeme Chester, John P. Owen, and Richard Lee, "Skeletal Growth Estimation Using Radiographic Image Processing and Analysis", IEEE Transactions On Information Technology In Biomedicine, Vol. 4, No. 4, December 2000, pp. 292 297.

66. E. Pietka Arkadiusz Gertych, Krzysztof Witko, "Informatics infrastructure of CAD system", Computerized Medical Imaging and Graphics 29, 2005, pp.157-169.

67. Cameriere R, Ferrante L, Mirtella D, Cingolani M., "Carpals and epiphyses of radius and ulna as age indicators”, Int J Legal Med. 2006; 120(3), pp. 143-146. DOI: 10.1007/s00414-005-00403.

68. Chi-Wen Hsieh,Tai-Lang Jong, Chui-Mei Tiu, "Bone age estimation based on phalanx information with fuzzy constrain of carpals”, Med Bio Eng Computing, 2007, Vol 45, pp. 283295, DOI 10.1007/s11517-006-0155-9.

69. Jian Liu, Jing Qi, Zhao Liu, Qin Ning, Xiaoping Luo, “Automatic bone age assessment based on intelligent algorithms and comparison with TW3 method”,Computerized Medical Imaging and Graphics 32, 2008, pp. 678-684.

70. Antonio Tristan-Vega and Juan Ignacio Arribas, "A Radius and Ulna TW3 Bone Age Assessment System”, IEEE Transactions on Biomedical Engineering, Vol. 55, No. 5, May 2008, pp.14631476.

71. Thodberg, H. H., Kreiborg, S., Juul, A., and Pedersen, K. D., "The BoneXpert method for automated determination of skeletal maturity”, IEEE Transactions on Medical Imaging, 2009, 28(1), pp. 52-66.

72. Marco Tise, Laura Mazzarini, Giancarlo Fabrizzi, Luigi Ferrante, Raffaele Giorgetti, Adriano Tagliabracci, "Applicability of Greulich and Pyle method for age assessment in forensic practice on an Italian sample”, Int J Legal Med 2011, Vol. 125, pp. 411-416, DOI 10.1007/s00414-0100541-6.

73. Krit Somkantha, Nipon Theera-Umpon and Sansanee Auephanwiriyakul, "Bone Age Assessment in Young Children Using Automatic Carpal Bone Feature Extraction and Support Vector Regression”, J Digit Imaging, 2011, Vol 24, pp. 1044-1058, DOI 10.1007/s10278-011-9372-3.

74. Jinwoo Seok, Baro Hyun, Josephine Kasa-Vubu and Anouck Girard, “Automated Classification System for Bone Age X-ray Images”, IEEE International Conference on Systems, Man, and Cybernetics, October 14-17, 2012, COEX, Seoul, Korea, DOI: 10.1109/ICSMC.2012.6377701.

75. Marjan Mansourvar, Maizatul Akmar Ismail, “Automatic Method for Bone Age Assessment Based on Combined Method”, IEEE conference paper,2014. 
76. Darko Stern, Martin Urschler, "From Individual Hand Bone Age Estimates To Fully Automated Age Estimation Via Learning-Based Information Fusion”, IEEE, 2016, PP. 150-154

77. Ji Zhang, Fangqin Lin, Xiaoyi Ding, "Maturation Disparity between Hand-Wrist Bones in a Chinese Sample of Normal Children: An Analysis Based on Automatic boneXpert and Manual Greulich and Pyle Atlas Assessment”, Korean J Radiol 2016,17(3), pp. 435-442 DOI: 10.3348/kjr.2016.17.3.435.

78. Bernhard Neumayer, Matthias Schloegl, Christian Payer, Thomas Widek, Sebastian Tschauner, Thomas Ehammer, Rudolf Stollberger and Martin Urschler, "Reducing acquisition time for MRI based forensic age estimation”, Scientific Reports, 2018, DOI:10.1038/s41598-018-20475-1.

79. Ellis R. Kerley Am., "The Microscopic Determination of Age in Human Bone”, J. Phys.A Nthrop., 23, pp. 149-164.

80. J. Singh and D. L. Gunberg, "Age Estimation of Age at Death in Human Males from Quantitative Histology of Bone Fragments”, J. Phys. Anthrop.,Vol 33, pp. 373-382.

81. Robert A. Walker and C. Owen Lovejoy, "Radiographic Changes in the Clavicle and Proximal Femur and Their Use in the Determination of Skeletal Age at Death", American Journal of Physical Anthropology, 1985, pp. 6857-78.

82. M.F. Ericksen, "Histologic Estimation of Age at Death Using the Anterior Cortex of the Femur", American Journal Of Physical Anthropology Vol. 84, 1991, pp. 171-179.

83. Faridah Mohd Nor, Robert F Pastor and Holger Schutkowski, "Age at death estimation from bone histology in Malaysian males”, Med Sci Law, 2013, DOI: 10.1177/0025802413506573.

84. jaz Khan, Muhammad Mahadi Abdul Jamil,Tengku Nadzlin Tengku Ibrahim, Faridah Mohd Nor, "Automated Human Age Estimation at Death via Bone Microstructures", 2016 6th IEEE International Conference on Control System.

85. Vidyashree H S, Pradeep N., "Identification of Teeth, Wrist and Femur Bone Features for Age and Gender Identifiction”, IJCSE, Vol. 6 No.01, Jan 2017.

86. K.F. Kreitner, F. J.Schweden, T. Riepert, B.Nafe, M. Thelen, "Bone age determination based on the study of the medial extremity of the clavicle”, Musculoskeletal radiology, Eur. Radiol. 8, Springer-Verlag 1998.pp.1116-1122.

87. Andreas Schmeling, Ronald Schulz, Walter Reisinger, Matthias Muhler, Klaus-Dieter, Wernecke Gunther, Geserick, "Studies on the time frame for ossification of the medial clavicular epiphyseal cartilage in conventional radiography", Int J Legal Med 2004, 118, pp. 5-8, DOI 10.1007/s00414-003-0404-5 .

88. Ronald Schulz, Matthias Mühler, Sven Mutze, Sven Schmidt, Walter Reisinger, Andreas Schmeling, "Studies on the time frame for ossification of the medial epiphysis of the clavicle as revealed by CT scans”, Int J Legal Med 2005, 119, pp. 142-145, DOI 10.1007/s00414-005-05299.

89. Matthias Muhler, Ronald Schulz, Sven Schmidt, Andreas Schmeling, Walter Reisinger, "The influence of slice thickness on assessment of clavicle ossification in forensic age diagnostics", Int J Leg Med 2006, 120, pp. 15-17, DOI 10.1007/s00414-005-0010-9.

90. Sven Schmidt, Matthias Muhler, Andreas Schmeling,Walter Reisinger, Ronald Schulz, "Magnetic resonance imaging of the clavicular ossification”, Int J Legal Med 2007, 121, pp. 321-324, DOI 10.1007/s00414-007-0160-z

91. Manuel Kellinghaus, Ronald Schulz, Volker Vieth, Sven Schmidt, Heidi Pfeiffer, Andreas Schmeling, "Enhanced possibilities to make statements on the ossification status of the medial clavicular epiphysis using an amplified staging scheme in evaluating thin-slice CT scans", Int $\mathrm{J}$ Legal Med 2010, 124, pp. 321-325, DOI 10.1007/s00414-010-0448-2.

92. E. Hillewig et al., "Magnetic resonance imaging of the sternal extremity of the clavicle in forensic age estimation: towards more sound age estimates”, Int J Legal Med 2013, 127, pp. 677-689, DOI 10.1007/s00414-012-0798-z.

93. Ronald Schulz, Manfred Schiborr, Heidi Pfeiffer, Sven Schmidt, Andreas Schmeling, "Sonographic assessment of the ossification of the medial clavicular epiphysis in 616 individuals”, Forensic Sci Med Pathol 2013, 9, pp. 351-357, DOI 10.1007/s12024-013-9440-8.

94. Daniel Wittschieber et al., "The value of sub-stages and thin slices for the assessment of the medial clavicular epiphysis: a prospective multi-center CT study”, Forensic Sci Med Pathol, DOI 10.1007/s12024-013-9511-x.

95. Inthasan C, Mahakkanukrauh P, “Age Estimation from Clavicle by Histomorphometry Method: A Review”, Med \& Health Jun 2017, 12(1), pp. 4-17.

96. Erik Westerberg, "AI-based Age Estimation using X-ray Hand Images", Thesis, Faculty of Computing Blekinge Institute of Technology, SE-371 79 Karlskrona, Sweden, June 2020. 